\title{
Optimum semiconductor bandgaps in single junction and multijunction thermophotovoltaic converters
}

\author{
A. Datas
}

\begin{abstract}
A B S T R A C T
The choice of the optimum semiconductor for manufacturing thermophotovoltaic (TPV) cells is not straightforward. In contrast to conventional solar photovoltaics (PV) where the optimum semiconductor bandgap is determined solely by the spectrum (and eventually the irradiance) of the incident solar light, in a TPV converter it depends on the emitter temperature and on the spectral control elements determining the net spectral power flux between the TPV cell and the emitter. Additionally, in TPV converters there is a tradeoff between power density and conversion efficiency that does not exist in conventional solar PV systems. Thus, the choice of the proper semiconductor compound in TPV converters requires a thorough analysis that has not been presented so far. This paper presents the optimum semiconductor bandgaps leading to the maximum efficiency and power density in TPV converters using both single junction and multijunction TPV cells. These results were obtained within the framework of the detailed balance theory and assuming only radiative recombination. Optimal bandgaps are provided as a function of the emitter and cell temperature, as well as the degree of spectral control. I show that multijunction TPV cells are excellent candidates to maximize both the efficiency and the power density simultaneously, eliminating the historical tradeoff between efficiency and power density of TPV converters. Finally, multijunction TPV cells are less sensitive to photon recycling losses, which suggest that they can be combined with relatively simple cut-off spectral control systems to provide practically-viable high performing TPV devices.
\end{abstract}

\section{Introduction}

Thermophotovoltaic (TPV) devices perform a direct heat-toelectricity conversion by using photovoltaic cells [1,2]. A basic TPV device comprises two elements: an emitter, which is heated by an external heat source, and a photovoltaic cell, referred to herein as a TPV cell, which is illuminated by the thermal radiation emitted by the emitter in order to produce electricity. In this arrangement, spectral control elements (selective emitters, filters, reflectors, etc) may be used to produce spectrally selective thermal radiation matching the TPV cell spectral response. This leads to a very high theoretical efficiency for TPV devices, approaching the Carnot efficiency in the limit of that TPV cells are illuminated by monochromatic light [3].

TPV technology offers a series of advantages compared with other heat engines: (1) it enables extremely high temperature operation, owing to the absence of physical contact between the hot and cold reservoirs, (2) it is a modular and scalable technology with an extremely low weight and volume, leading to extraordinary high specific power and energy densities, (3) it does not use moving parts, which minimizes the maintenance requirements and enables low noise operation, and (4) it may enable very high heat-to-electricity conversion efficiency, ideally as high as a Carnot engine.

The above characteristics combined with the many different possible sources of heat led to a broad range of applications for TPV technology, including heat recovery from high temperature industrial processes [4-6], combined heat and power for residential use [7-11], solar power [3,12-18], portable energy sources [8,19-21], space power [22-26], energy storage systems [16,25-27], among others.

The best experimental radiant heat to electricity conversion efficiency reported so far for a TPV device is of $23.6 \%$, using a SiC emitter at $1039^{\circ} \mathrm{C}$ and InGaAs $(0.6 \mathrm{eV})$ single junction TPV cells conforming a monolithic interconnected module (MIM) [28]. Similar values have been reported by other authors by using GaSb $(0.74 \mathrm{eV})$ single junction TPV cells [29] and InGaAsSb $(0.53 \mathrm{eV})$ quaternary compounds [30,31]. Concerning power density, values of up to $2.5 \mathrm{~W} / \mathrm{cm}^{2}$ have been measured using $\mathrm{SiC}$ emitter at 


\begin{tabular}{|c|c|c|c|}
\hline \multicolumn{2}{|c|}{ Nomenclature } & $T_{e}$ & emitter temperature $\left({ }^{\circ} \mathrm{C}\right)$ \\
\hline A & area $\left(\mathrm{cm}^{2}\right)$ & $V_{k}$ & voltage generated by the $k^{\text {th }}$ sub-cell, where $k=1$ \\
\hline$A_{c}$ & TPV cell area $\left(\mathrm{cm}^{2}\right)$ & & corresponds to the top-cell (V) \\
\hline$A_{e}$ & emitter area $\left(\mathrm{cm}^{2}\right)$ & $V$ & total output voltage generated by the TPV cell $(\mathrm{V})$ \\
\hline$c$ & speed of light in vacuum $(\mathrm{cm} / \mathrm{s})$ & $V_{M P}$ & output voltage generated by the TPV cell at the \\
\hline$\dot{E}$ & normal radiative energy flux $\left(\mathrm{W} / \mathrm{cm}^{2} \mathrm{sr}\right)$ & & maximum power point $(\mathrm{V})$ \\
\hline$F_{e c}$ & emitter-to-cell view factor & $V_{O C}$ & open-circuit voltage of the TPV cell (V) \\
\hline$F_{c c}^{(e)}$ & $\begin{array}{l}\text { cell-to-cell view factor when the emitter is a shadow- } \\
\text { ing element }\end{array}$ & $\varepsilon_{k}$ & $\begin{array}{l}\text { bandgap energy of the semiconductor used in the } k^{t h} \\
\text { sub-cell, where } k=1 \text { corresponds to the top-cell }(\mathrm{eV})\end{array}$ \\
\hline$h$ & Plank constant $\left(\mathrm{cm}^{2} \mathrm{~kg} / \mathrm{s}\right)$ & $\varepsilon_{G}$ & bandgap energy of the semiconductor used in a single \\
\hline$J_{k}$ & $\begin{array}{l}\text { electrical current density generated by the } k^{\text {th } h} \text { sub-cell, } \\
\text { where } k=1 \text { corresponds to the top-cell }\left(\mathrm{A} / \mathrm{cm}^{2}\right)\end{array}$ & $\varepsilon_{c e}$ & $\begin{array}{l}\text { homo-junction PV cell (eV) } \\
\text { cut-off energy of the emitter (eV) }\end{array}$ \\
\hline$J$ & $\begin{array}{l}\text { electrical current density generated by the TPV cell } \\
\left(\mathrm{A} / \mathrm{cm}^{2}\right)\end{array}$ & $\begin{array}{l}\eta \\
\eta_{t h}\end{array}$ & $\begin{array}{l}\text { conversion efficiency } \\
\text { thermal efficiency }\end{array}$ \\
\hline$J_{M P}$ & $\begin{array}{l}\text { electrical current density generated by the TPV cell at } \\
\text { the maximum power point }\left(\mathrm{A} / \mathrm{cm}^{2}\right)\end{array}$ & $\eta_{\mathrm{TPV}}$ & $\begin{array}{l}\text { TPV efficiency } \\
\text { photon electrochemical potential }(\mathrm{eV})\end{array}$ \\
\hline $\begin{array}{l}J_{S C} \\
k\end{array}$ & $\begin{array}{l}\text { short-circuit current density of the TPV cell }\left(\mathrm{A} / \mathrm{cm}^{2}\right) \\
\text { Boltzmann constant }\left(\mathrm{cm}^{2} \mathrm{~kg} \mathrm{~s}^{-2} \mathrm{~K}^{-1}\right)\end{array}$ & $\rho_{\mathrm{BSR}}$ & $\begin{array}{l}\text { reflectivity of the semiconductor-BSR interface (for all } \\
\text { wavelengths) }\end{array}$ \\
\hline$n$ & number of sub-cells in the multijunction TPV cell & \multirow{2}{*}{\multicolumn{2}{|c|}{ Abbreviations }} \\
\hline$N$ & normal photon flux (no. photons $/ \mathrm{cm}^{2} \mathrm{sr}-\mathrm{s}$ ) & & \\
\hline$n_{\text {int }}$ & TPV cell semiconductor refraction index & & \\
\hline Pout & $\begin{array}{l}\text { radiative power density outgoing from the emitter } \\
\left(\mathrm{W} / \mathrm{cm}^{2}\right)\end{array}$ & $\begin{array}{l}\text { MJC } \\
\text { TPV }\end{array}$ & $\begin{array}{l}\text { multijunction cell } \\
\text { thermophotovoltaic }\end{array}$ \\
\hline$P_{\text {in }}$ & $\begin{array}{l}\text { radiative power density incoming to the emitter } \\
\left(\mathrm{W} / \mathrm{cm}^{2}\right)\end{array}$ & $\begin{array}{l}\text { BSR } \\
1 \mathrm{IC}\end{array}$ & $\begin{array}{l}\text { back surface reflector } \\
\text { single junction TPV cell }\end{array}$ \\
\hline$P_{E L}$ & output electrical power density $\left(\mathrm{W} / \mathrm{cm}^{2}\right)$ & $2 \mathrm{JC}$ & dual junction TPV cell \\
\hline $\begin{array}{l}q \\
Q_{\text {in }} \\
T\end{array}$ & $\begin{array}{l}\text { electron charge }(\mathrm{C}) \\
\text { external heat input }\left(\mathrm{W} / \mathrm{cm}^{2}\right) \\
\text { temperature }\left({ }^{\circ} \mathrm{C}\right)\end{array}$ & $3 \mathrm{JC}$ & triple junction TPV cell \\
\hline
\end{tabular}

$1450{ }^{\circ} \mathrm{C}$ and $\mathrm{GaSb}(0.74 \mathrm{eV})$ single junction TPV cells [32]. However, much higher efficiencies and power densities are achievable, at least theoretically, by TPV converters [1-3,33].

In order to increase the conversion efficiency and power density of current state-of-the-art TPV converters, research focuses on both optimizing the semiconductor TPV cell structure and on finding the proper arrangements for tuning the spectrum of the radiation exchanged between the TPV cell and the emitter. With respect to the latter, TPV converters may be classified according to the type of spectral control strategy: cut-off or narrow-band.

Narrow-band strategies attempt at creating a quasi-monochromatic radiative exchange between the emitter and a single junction TPV cell. Single junction PV cells have already demonstrated conversion efficiencies above $50 \%$ under monochromatic illumination using a laser light source [34]. Therefore, the current challenge of narrowband TPV approach consists of developing the appropriate emitter element to produce high quality quasi-monochromatic thermal emission at high temperatures [35]. The key fundamental drawback of this approach, independently of its particular implementation, relies on the low output power density, which is related to the low density of photonic modes of the monochromatic light. Novel concepts based on near-field effects may enhance the monochromatic power density beyond the classical limits [36,37], but these concepts are still in a very early stage of development and are not considered in this study.

This work focuses on cut-off spectral control strategies in which the radiative exchange between the emitter and the TPV cell is restricted to those photons with energies above the TPV cell's bandgap. This arrangement provides higher power density and enables the use of simpler elements on the (hot) emitter side; thus it is more readily implementable in practice.
The main drawback of this approach is the lower bound for the conversion efficiency. However, this study demonstrates that this drawback may be overcome by using multijunction TPV cells. Although experimental work on multijunction TPV cell structures has been presented previously [38-42], a thorough theoretical analysis on their potential for TPV energy conversion is missing.

This paper presents a global optimization of single junction and multijunction TPV devices comprising cut-off spectral control elements. The optimum semiconductor bandgap(s) are calculated as a function of the emitter and cell temperatures, and the quality of the spectral control (i.e. photon recycling efficiency). Optimums for both

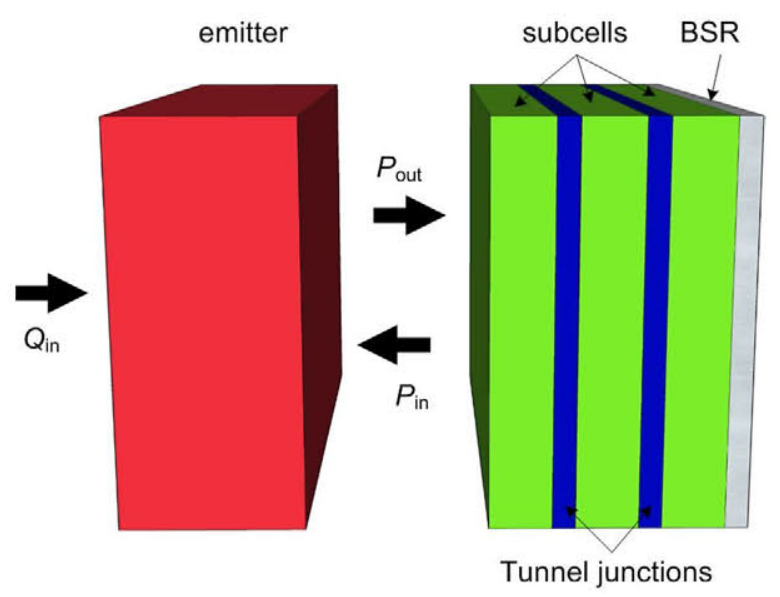

Fig. 1. Multijunction TPV converter with integrated BSR. 
Table 1

Summary of the equations used in this work for modelling the TPV device. Taken from Ref. [15].

\begin{tabular}{|c|c|}
\hline Photon flux in the spectral interval $\left(\varepsilon_{i}, \varepsilon_{k}\right)$ & $\dot{N}\left(\varepsilon_{i}, \varepsilon_{k}, T, \mu\right)=\frac{2}{h^{3} c^{2}} \int_{\varepsilon_{i}}^{\varepsilon_{k}} \frac{\varepsilon^{2}}{\exp [(\varepsilon-\mu) / k T]-1} d \varepsilon$ \\
\hline Energy of the photon flux in the spectral interval $\left(\varepsilon_{i}, \varepsilon_{k}\right)$ & $\dot{E}\left(\varepsilon_{i}, \varepsilon_{k}, T, \mu\right)=\frac{2}{h^{3} c^{2}} \int_{\varepsilon_{i}}^{\varepsilon_{k}} \frac{\varepsilon^{3}}{\exp [(\varepsilon-\mu) / k T]-1} d \varepsilon$ \\
\hline Photo-current generated in a single junction cell & $\begin{aligned} \frac{J}{q \pi} & =\frac{A_{e}}{A_{c}} F_{e c} \dot{N}\left(\varepsilon_{G}, \infty, T_{e}, 0\right)-\left(1-F_{c}^{(e)}\right) \dot{N}\left(\varepsilon_{G}, \infty, T_{c}, q V\right) \\
& -n_{i n t}^{2}\left(1-\dot{\rho}_{\mathrm{BSR}}\right) N\left(\varepsilon_{G}, \infty, T_{c}, q V\right)\end{aligned}$ \\
\hline Photo-current generated in the top-subcell & $\begin{aligned} \frac{J_{1}}{q \pi} & =\frac{A_{e}}{A_{c}} F_{e c} \dot{N}\left(\varepsilon_{1}, \infty, T_{e}, 0\right)-\left(1-F_{c c}^{(e)}\right) \dot{N}\left(\varepsilon_{1}, \infty, T_{c}, q V_{1}\right) \\
& +n_{i n t}^{2}\left[\dot{N}\left(\varepsilon_{1}, \infty, T_{c}, q V_{2}\right)-\dot{N}\left(\varepsilon_{1}, \infty, T_{c}, q V_{1}\right)\right]\end{aligned}$ \\
\hline Photo-current generated in the bottom sub-cell & $\begin{aligned} \frac{J_{n}}{q \pi} & =\frac{A_{e}}{A_{c}} F_{e c} \dot{N}\left(\varepsilon_{n}, \varepsilon_{n-1}, T_{e}, 0\right)-\left(1-F_{c c}^{(e)}\right) \dot{N}\left(\varepsilon_{n}, \varepsilon_{n-1}, T_{c}, q V_{n}\right) \\
& +n_{i n t}^{2}\left[\dot{N}\left(\varepsilon_{n-1}, \infty, T_{c}, q V_{n-1}\right)-\dot{N}\left(\varepsilon_{n-1}, \infty, T_{c}, q V_{n}\right)\right. \\
& \left.-\left(1-\rho_{\mathrm{BSR}}\right) \dot{N}\left(\varepsilon_{n}, \infty, T_{c}, q V_{n}\right)\right]\end{aligned}$ \\
\hline Photo-current generated in an intermediate sub-cell & $\begin{aligned} \frac{J_{k}}{q \pi} & =\frac{A_{e}}{A_{c}} F_{e c} \dot{N}\left(\varepsilon_{k}, \varepsilon_{k-1}, T_{e}, 0\right)-\left(1-F_{c c}^{(e)}\right) \dot{N}\left(\varepsilon_{k}, \varepsilon_{k-1}, T_{c}, q V_{k}\right) \\
& +n_{i n t}^{2}\left[\dot{N}\left(\varepsilon_{k-1}, \infty, T_{c}, q V_{k-1}\right)+\dot{N}\left(\varepsilon_{k}, \infty, T_{c}, q V_{k+1}\right)\right. \\
& \left.-\dot{N}\left(\varepsilon_{k}, \infty, T_{c}, q V_{k}\right)-\dot{N}\left(\varepsilon_{k-1}, \infty, T_{c}, q V_{k}\right)\right]\end{aligned}$ \\
\hline $\begin{array}{l}\text { Net radiative power outgoing from the emitter towards the cells (single } \\
\text { junction) }\end{array}$ & $\begin{array}{l}\left(P_{\text {out }}-P_{i n}\right) / \pi=F_{\mathrm{ec}} \dot{E}\left(\varepsilon_{G}, \infty, T_{c}, q V\right)-\dot{E}\left(\varepsilon_{c e}, \infty, T_{e}, 0\right) \\
\quad+\frac{A_{e}}{A_{c}} \cdot \frac{\rho_{\mathrm{BSR}} F_{e c}^{2}}{1-\rho_{\mathrm{BSR}} F_{c \mathrm{c}}^{(e)}} \dot{E}\left(\varepsilon_{c e}, \varepsilon_{G}, T_{e}, 0\right)\end{array}$ \\
\hline $\begin{array}{l}\text { Net radiative power outgoing from the emitter towards the cells } \\
\text { (multijunction) }\end{array}$ & $\begin{array}{l}\left(P_{\text {out }}-P_{\text {in }}\right) / \pi=F_{e c} \sum_{k=1}^{n} \dot{E}\left(\varepsilon_{k}, \varepsilon_{k-1}, T_{c}, q V_{k}\right)-\dot{E}\left(\varepsilon_{c e}, \infty, T_{e}, 0\right) \\
\quad+\frac{A_{e}}{A_{c}} \times \frac{\rho_{\mathrm{BSR}} F_{e c}^{2}}{1-\rho_{\mathrm{BSR}} F_{c c}^{(e)}} \dot{E}\left(\varepsilon_{c e}, \varepsilon_{n}, T_{e}, 0\right)\end{array}$ \\
\hline
\end{tabular}

efficiency and electrical power density maximization are presented. The calculations are based on the detailed balance theory and assume only radiative recombination in the TPV cells, and therefore represent the upper bounds for efficiency (and power density).

\section{Theoretical background}

Fig. 1 shows a sketch of the TPV device that will be analyzed in this study. It comprises an emitter and a TPV cell with integrated back surface reflector (BSR) which reflects back to the emitter the sub-bandgap (non absorbed) radiation [43-46]. The TPV cell may consist of either single junction or multijunction device. Multijunction cells comprise two or more subcells stacked one on top each other, with the higher bandgap cell placed on top, so that each subcell converts a different part of the incident spectrum with higher efficiency. The cells may be connected in series by means of transparent tunnel diodes, as shown in Fig. 1. External heat is supplied to the emitter, which in turns radiates towards the TPV cell, which produces electricity. The sub-bandgap photons, not absorbed by the TPV cell, are reflected back to the emitter, by means of the BSR. The semiconductor-BSR interface is assumed to have a reflectivity $\rho_{\mathrm{BSR}}$, independently of the photon energy.

It worth noting that cut-off spectral control in TPV may be implemented by other elements rather than BSRs, for instance: a filter located in between the emitter and the cells $[47,48]$ or an micro-engineered emitter surface [49-51]. However, all of these arrangements are equivalent from the theoretical point of view and their common effect on the TPV overall performance is of that modifying the equivalent sub-bandgap emitter emissivity, which can be defined as the ratio of the net flux of photons that leave the emitter surface within the TPV optical cavity (formed by the emitter and TPV cell) to the flux of photons that radiates a black-body at the same temperature towards the free space. Therefore, the use of BSR does not represent a loss of generality and the main conclusions extracted from an analysis of this configuration will apply to any other cut-off spectral control strategy. The only aspect in which the use of BSR differentiates from other spectral control mechanisms is that backwards luminescence from the TPV cell is also recycled, reducing the net recombination. This may improve significantly the TPV cell performance.

The TPV efficiency is defined as the ratio of the electric power produced by the TPV cells $\left(P_{E L}\right)$ to the net thermal power outgoing from the side of the emitter facing the cells $\left(P_{\text {out }}-P_{\text {in }}\right)$. The total heat-to-electricity efficiency of a TPV device is calculated by the product of the TPV efficiency and the thermal efficiency, defined as the ratio of the net thermal power radiated by the emitter towards the TPV cell $\left(P_{\text {out }}-P_{\text {in }}\right)$ to the heat supplied externally to the emitter $\left(Q_{i n}\right)$ :

$\eta=\eta_{\text {th }} \times \eta_{\mathrm{TPV}}=\frac{P_{\text {out }}-P_{\text {in }}}{Q_{\text {in }}} \times \frac{P_{E L}}{P_{\text {out }}-P_{\text {in }}}$

The power radiated by the emitter $\left(P_{\text {out }}\right)$ depends exclusively on the emitter temperature and emitter spectral emissivity. However, the power reabsorbed by the emitter $\left(P_{i n}\right)$ depends also on the 
Table 2

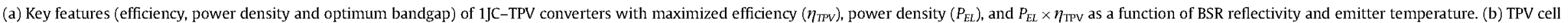

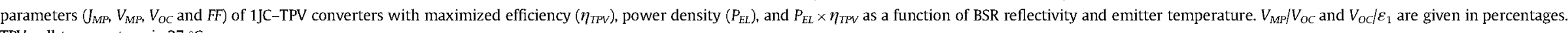
TPV cell temperature is $27^{\circ} \mathrm{C}$.

\begin{tabular}{|c|c|c|c|c|c|c|c|c|c|c|c|c|c|c|}
\hline \multirow[t]{2}{*}{ (a) $1 \mathrm{JC}$ and $T_{c}=27^{\circ} \mathrm{C}$} & & \multirow[b]{2}{*}{$\rho_{B S R}$} & \multicolumn{4}{|c|}{ Maximum $\eta_{\mathrm{TPV}}$} & \multicolumn{4}{|c|}{ Maximum $P_{E L}$} & \multicolumn{4}{|c|}{ Maximum $P_{E L} \times \eta_{T P V}$} \\
\hline & & & 0.00 & 0.60 & 0.90 & 0.99 & 0.00 & 0.60 & 0.90 & 0.99 & 0.00 & 0.60 & 0.90 & 0.99 \\
\hline \multirow{24}{*}{ Emitter temperature, $T_{e}\left({ }^{\circ} \mathrm{C}\right)$} & 2000 & $\eta_{\mathrm{TPV}}$ & 29.3 & 38.0 & 50.0 & 61.3 & 29.3 & 36.4 & 42.1 & 45.3 & 29.3 & 37.4 & 46.0 & 51.0 \\
\hline & & $P_{E L}\left(\mathrm{~W} / \mathrm{cm}^{2}\right)$ & 44.7 & 44.9 & 36.7 & 20.3 & 44.7 & 47.5 & 51.0 & 53.5 & 44.7 & 47.0 & 49.2 & 50.9 \\
\hline & & $\varepsilon_{1}(\mathrm{eV})$ & 0.462 & 0.570 & 0.756 & 1.032 & 0.462 & 0.445 & 0.426 & 0.415 & 0.462 & 0.498 & 0.526 & 0.534 \\
\hline & 1800 & $\eta_{\mathrm{TPV}}$ & 28.0 & 36.7 & 48.5 & 60.2 & 28.0 & 35.1 & 41.0 & 44.4 & 28.0 & 36.2 & 44.8 & 49.9 \\
\hline & & $P_{E L}\left(\mathrm{~W} / \mathrm{cm}^{2}\right)$ & 29.6 & 29.9 & 24.7 & 13.7 & 29.6 & 31.7 & 34.3 & 36.2 & 29.6 & 31.3 & 33.1 & 34.4 \\
\hline & & $\varepsilon_{1}(\mathrm{eV})$ & 0.426 & 0.523 & 0.692 & 0.941 & 0.426 & 0.408 & 0.389 & 0.378 & 0.426 & 0.457 & 0.480 & 0.486 \\
\hline & 1600 & $\eta_{T P V}$ & 26.5 & 35.2 & 47.0 & 58.8 & 26.5 & 33.7 & 39.7 & 43.3 & 26.5 & 34.7 & 43.5 & 48.8 \\
\hline & & $P_{E L}\left(\mathrm{~W} / \mathrm{cm}^{2}\right)$ & 18.6 & 19.0 & 15.8 & 8.9 & 18.6 & 20.1 & 22.1 & 23.4 & 18.6 & 19.9 & 21.3 & 22.3 \\
\hline & & $\varepsilon_{1}(\mathrm{eV})$ & 0.390 & 0.477 & 0.627 & 0.850 & 0.390 & 0.372 & 0.352 & 0.340 & 0.390 & 0.416 & 0.436 & 0.440 \\
\hline & 1400 & $\eta_{T P V}$ & 24.7 & 33.3 & 45.2 & 57.1 & 24.7 & 31.8 & 38.1 & 41.9 & 24.7 & 32.8 & 41.7 & 47.2 \\
\hline & & $P_{E L}\left(\mathrm{~W} / \mathrm{cm}^{2}\right)$ & 11.0 & 11.4 & 9.6 & 5.4 & 11.0 & 12.1 & 13.4 & 14.4 & 11.0 & 11.9 & 12.9 & 13.7 \\
\hline & & $\varepsilon_{1}(\mathrm{eV})$ & 0.355 & 0.430 & 0.562 & 0.759 & 0.355 & 0.336 & 0.315 & 0.303 & 0.355 & 0.376 & 0.391 & 0.391 \\
\hline & 1200 & $\eta_{T P V}$ & 22.4 & 31.0 & 42.9 & 55.0 & 22.4 & 29.6 & 36.0 & 40.2 & 22.4 & 30.5 & 39.6 & 45.3 \\
\hline & & $P_{E L}\left(\mathrm{~W} / \mathrm{cm}^{2}\right)$ & 6.0 & 6.3 & 5.4 & 3.1 & 6.0 & 6.7 & 7.6 & 8.2 & 6.0 & 6.6 & 7.3 & 7.8 \\
\hline & & $\varepsilon_{1}(\mathrm{eV})$ & 0.320 & 0.384 & 0.498 & 0.668 & 0.320 & 0.300 & 0.279 & 0.266 & 0.320 & 0.336 & 0.347 & 0.345 \\
\hline & 1000 & $\eta_{T P V}$ & 19.5 & 28.0 & 39.9 & 52.2 & 19.5 & 26.7 & 33.4 & 38.0 & 19.5 & 27.6 & 36.8 & 42.8 \\
\hline & & $P_{E L}\left(\mathrm{~W} / \mathrm{cm}^{2}\right)$ & 2.9 & 3.2 & 2.8 & 1.6 & 2.9 & 3.3 & 3.9 & 4.3 & 2.9 & 3.3 & 3.7 & 4.1 \\
\hline & & $\varepsilon_{1}(\mathrm{eV})$ & 0.286 & 0.339 & 0.433 & 0.577 & 0.286 & 0.265 & 0.242 & 0.228 & 0.286 & 0.297 & 0.302 & 0.297 \\
\hline & 800 & $\eta_{T P V}$ & 15.9 & 24.1 & 36.0 & 48.4 & 15.9 & 22.9 & 23.0 & 35.0 & 15.9 & 23.7 & 33.1 & 39.5 \\
\hline & & $P_{E L}\left(\mathrm{~W} / \mathrm{cm}^{2}\right)$ & 1.20 & 1.34 & 1.23 & 0.74 & 1.20 & 1.42 & 1.73 & 1.97 & 1.20 & 1.40 & 1.66 & 1.87 \\
\hline & & $\varepsilon_{1}(\mathrm{eV})$ & 0.255 & 0.294 & 0.370 & 0.486 & 0.255 & 0.232 & 0.206 & 0.191 & 0.255 & 0.259 & 0.258 & 0.250 \\
\hline & 600 & $\eta_{T P V}$ & 11.1 & 18.7 & 30.2 & 41.5 & 11.1 & 17.8 & 25.1 & 30.8 & 11.1 & 18.4 & 27.9 & 34.8 \\
\hline & & $P_{E L}\left(\mathrm{~W} / \mathrm{cm}^{2}\right)$ & 0.37 & 0.44 & 0.44 & 0.28 & 0.37 & 0.47 & 0.62 & 0.74 & 0.37 & 0.46 & 0.59 & 0.70 \\
\hline & & $\varepsilon_{1}(\mathrm{eV})$ & 0.227 & 0.252 & 0.308 & 0.403 & 0.227 & 0.201 & 0.171 & 0.154 & 0.227 & 0.223 & 0.215 & 0.203 \\
\hline \multirow[t]{2}{*}{ (b) $1 \mathrm{JC}$ and $T_{\mathrm{c}}=27^{\circ} \mathrm{C}$} & & & \multicolumn{4}{|c|}{ Maximum $\eta_{\mathrm{TPV}}$} & \multicolumn{4}{|c|}{ Maximum $P_{E L}$} & \multicolumn{4}{|c|}{ Maximum $P_{E L} \times \eta_{T P V}$} \\
\hline & & $\rho_{B S R}$ & 0.00 & 0.60 & 0.90 & 0.99 & 0.00 & 0.60 & 0.90 & 0.99 & 0.00 & 0.60 & 0.90 & 0.99 \\
\hline \multirow[t]{21}{*}{ Emitter temperature. $T_{e}\left({ }^{\circ} \mathrm{C}\right)$} & 2000 & $J_{M P}\left(\mathrm{~A} / \mathrm{cm}^{2}\right)$ & 132.8 & 101.8 & 59.76 & 24.03 & 132.8 & 138.6 & 145.5 & 149.7 & 132.76 & 122.34 & 114.53 & 112.50 \\
\hline & & $V_{M P} / V_{O C}$ & 83.38 & 85.73 & 88.28 & 90.47 & 83.38 & 83.89 & 85.21 & 87.07 & 83.38 & 84.71 & 86.07 & 87.12 \\
\hline & & $V_{o d} \varepsilon_{1}$ & 87.38 & 90.31 & 92.32 & 92.34 & 87.38 & 91.80 & 96.64 & 98.96 & 87.38 & 91.07 & 94.93 & 97.26 \\
\hline & & & 77.45 & 81.00 & 84.74 & 87.83 & 77.45 & 78.05 & 79.50 & 81.49 & 77.45 & 79.40 & 81.24 & 82.51 \\
\hline & 1800 & $J_{M P}\left(\mathrm{~A} / \mathrm{cm}^{2}\right)$ & 98.59 & 76.00 & 44.73 & 18.18 & 98.59 & 103.7 & 109.3 & 112.9 & 98.58 & 91.38 & 86.23 & 85.06 \\
\hline & & $V_{M P} / V_{O C}$ & 82.29 & 84.75 & 87.45 & 89.75 & 82.29 & 82.80 & 84.13 & 86.02 & 82.29 & 83.67 & 85.08 & 86.16 \\
\hline & & $V_{o d} \varepsilon_{1}$ & 85.53 & 88.88 & 91.21 & 91.34 & 85.53 & 90.40 & 95.86 & 98.61 & 85.53 & 89.65 & 94.00 & 96.66 \\
\hline & & & 75.78 & 79.55 & 83.55 & 86.84 & 75.78 & 76.39 & 77.88 & 79.91 & 75.78 & 77.84 & 79.77 & 81.09 \\
\hline & 1600 & $J_{M P}\left(\mathrm{~A} / \mathrm{cm}^{2}\right)$ & 70.82 & 54.77 & 32.58 & 13.37 & 70.82 & 74.92 & 79.73 & 82.85 & 70.82 & 66.11 & 62.62 & 62.09 \\
\hline & & $V_{M P} / V_{O C}$ & 81.03 & 83.62 & 86.46 & 88.89 & 81.03 & 81.56 & 82.88 & 84.79 & 81.03 & 82.47 & 83.95 & 85.05 \\
\hline & & $V_{o d} / \varepsilon_{1}$ & 83.21 & 87.06 & 89.82 & 90.10 & 83.21 & 88.59 & 94.82 & 98.14 & 83.21 & 87.84 & 92.75 & 95.83 \\
\hline & & & 73.80 & 77.85 & 82.11 & 85.64 & 73.80 & 74.46 & 75.96 & 78.04 & 73.80 & 75.98 & 78.07 & 79.44 \\
\hline & 1400 & $J_{M P}\left(\mathrm{~A} / \mathrm{cm}^{2}\right)$ & 48.64 & 38.04 & 22.85 & 9.48 & 48.64 & 52.02 & 55.99 & 58.47 & 48.64 & 45.82 & 43.90 & 44.12 \\
\hline & & $V_{M P} / V_{O C}$ & 79.55 & 82.26 & 85.27 & 87.86 & 79.55 & 80.08 & 81.40 & 83.33 & 79.55 & 81.05 & 82.59 & 83.71 \\
\hline & & $V_{o d} / \varepsilon_{1}$ & 80.25 & 84.74 & 88.03 & 88.52 & 80.25 & 86.24 & 93.41 & 97.43 & 80.25 & 85.48 & 91.13 & 94.79 \\
\hline & & $F F$ & 71.43 & 75.74 & 80.35 & 84.17 & 71.43 & 72.11 & 73.65 & 75.79 & 71.43 & 73.77 & 75.99 & 77.39 \\
\hline & 1200 & $J_{M P}\left(\mathrm{~A} / \mathrm{cm}^{2}\right)$ & 31.62 & 25.00 & 15.20 & 6.43 & 31.62 & 34.30 & 37.34 & 39.39 & 31.62 & 30.15 & 29.21 & 29.63 \\
\hline & & $V_{M P} / V_{O C}$ & 77.76 & 80.61 & 83.82 & 86.57 & 77.76 & 78.30 & 79.64 & 81.58 & 77.76 & 79.34 & 80.96 & 82.11 \\
\hline & & $V_{o d} / \varepsilon_{1}$ & 76.37 & 81.65 & 85.65 & 86.44 & 76.37 & 83.08 & 91.40 & 96.39 & 76.37 & 82.35 & 88.90 & 93.24 \\
\hline & & & 68.47 & $\begin{array}{l}73.15 \\
15.5\end{array}$ & 78.18 & 82.32 & 68.47 & 69.21 & 70.85 & 73.03 & 68.47 & 71.02 & 73.45 & 74.93 \\
\hline & 1000 & $J_{M P}\left(\mathrm{~A} / \mathrm{cm}^{2}\right)$ & 19.00 & 15.25 & 9.52 & 4.12 & 19.00 & 21.02 & 23.43 & 25.05 & 19.00 & 18.42 & 18.29 & 18.87 \\
\hline
\end{tabular}


spectral control elements within the TPV optical cavity, i.e. the BSR reflectivity. In a TPV device without any kind of spectral control $\left(\rho_{\mathrm{BSR}}=0\right)$, the power absorbed by the emitter, $P_{i n}$, is zero and thus $P_{E L}$ is simply proportional to the TPV efficiency. However, in a general case where $P_{i n}>0$, the TPV efficiency can be enhanced just by reducing $P_{\text {out }}-P_{\text {in }}$ (e.g. quasi-monochromatic radiative exchange between the emitter and the cells) which leads to a reduction of $P_{E L}$. Thus, efficiency and power density are not necessary equivalent in TPV systems.

It worth noting that making $P_{\text {out }}-P_{\text {in }}$ small affects not only the TPV efficiency, but also the thermal efficiency $\left(\eta_{t h}\right)$ so that the total heat-to-electricity efficiency $(\eta)$ can be drastically deteriorated if we focus only on reducing $P_{\text {out }}-P_{\text {in }}$ instead of increasing $P_{E L}$. In applications where the heat input $\left(Q_{i n}\right)$ is constant, such as in solar power, the strategy of maximizing $P_{E L}$ might be preferable. However, in applications where the emitter temperature is constant, such as in a phase change processes the strategy of maximizing the TPV efficiency might be preferable. This is because at constant emitter temperature, lowering $P_{\text {out }}-P_{\text {in }}$ forces $Q_{\text {in }}$ to be small in order to fulfill the energy balance in the emitter; thus, leading to a high thermal efficiency. In the case of a phase change process, this implies a longer solidifying time, which might be beneficial in some cases [16]. This illustrates that each application requires a particular analysis to figure out which is the optimum balance between efficiency and power density.

\section{Mathematical formulation and methodology}

We formulate this problem by means of the detailed balance theory, assuming that only radiative recombination takes place in the TPV cells. The equations that model the system are adapted to this case from reference [15] and are summarized in Table 1. Given the TPV cell parameters, i.e. bandgap $(s)\left(\varepsilon_{k}\right)$, refraction index $\left(n_{i n t}\right)$ and BSR reflectivity $\left(\rho_{\text {BSR }}\right)$, the geometrical configuration parameters, i.e. the emitter-to-cell and cell-to-cell view factors ( $F_{e c}$ and $\left.F_{c c}^{(e)}\right)$ and the emitter and cell temperatures $\left(T_{e}\right.$ and $\left.T_{c}\right)$ the equations listed in Table 1 are solved together with the following two extra equations for the current density and voltage in each subcell $\left(J_{i}\right.$ and $\left.V_{k}\right)$ :

$J=J_{i}=J_{k} \quad \forall \mathrm{i}, \mathrm{k}$

$V=\sum_{i=1}^{n} V_{i}$

which hold for series-connected multijunction cells. Solving this system of equations for different values of $V$ results in the $J-V$ curve of the TPV device. Then, the maximum power point is found by maximizing the $J-V$ product, leading to the maximum electrical power density delivered by the TPV device:

$P_{E L}=J_{M P} V_{M P}$

Finally, the TPV efficiency can be obtained from:

$\eta_{\mathrm{TPV}}=\frac{A_{c} P_{E L}}{A_{e}\left(P_{\text {out }}-P_{\text {in }}\right)}$

The objective of this study is to determine the optimum bandgap energies $\left(\varepsilon_{k}\right)$ as a function of the emitter temperature $\left(T_{e}\right)$, the TPV cell temperature $\left(T_{c}\right)$, and the photon recycling efficiency of the TPV device. In the particular TPV configuration analyzed here, the emitter is a black body $\left(\varepsilon_{c e}=0\right)$ and the spectral control is performed by a BSR (Fig. 1); thus, the photon recycling efficiency will depend on the BSR reflectivity $\left(\rho_{\mathrm{BSR}}\right)$. If $F_{e c} \rightarrow 1$, most of the radiative power reflected in the BSR (which is given by $\rho_{\mathrm{BSR}}$ ) is reabsorbed by the emitter and the photon recycling efficiency may be approximated by $\rho_{\mathrm{BSR}}$. In this study we assume $F_{e c}=0.99$ 
Table 3

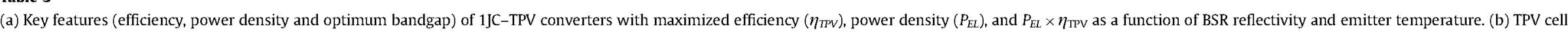

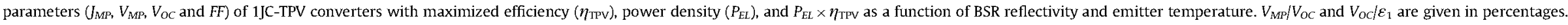
TPV cell temperature is $127^{\circ} \mathrm{C}$

\begin{tabular}{|c|c|c|c|c|c|c|c|c|c|c|c|c|c|c|}
\hline \multirow[t]{2}{*}{ (a) $1 \mathrm{JC}$ and $T_{c}=127^{\circ} \mathrm{C}$} & & \multirow[b]{2}{*}{$\rho_{B S R}$} & \multicolumn{4}{|c|}{ Maximum $\eta_{T P V}$} & \multicolumn{4}{|c|}{ Maximum $P_{E L}$} & \multicolumn{4}{|c|}{ Maximum $P_{E L} \times \eta_{T P V}$} \\
\hline & & & 0.00 & 0.60 & 0.90 & 0.99 & 0.00 & 0.60 & 0.90 & 0.99 & 0.00 & 0.60 & 0.90 & 0.99 \\
\hline \multirow{24}{*}{ Emitter temperature. $T_{e}\left({ }^{\circ} \mathrm{C}\right)$} & \multirow[t]{3}{*}{2000} & $\eta_{\mathrm{TPV}}$ & 25.0 & 33.6 & 45.4 & 56.5 & 25.0 & 32.2 & 38.3 & 42.2 & 25.0 & 33.1 & 42.0 & 47.5 \\
\hline & & $P_{E L}\left(\mathrm{~W} / \mathrm{cm}^{2}\right)$ & 38.1 & 39.3 & 33.0 & 18.7 & 38.1 & 41.6 & 46.1 & 49.3 & 38.1 & 41.1 & 44.4 & 46.9 \\
\hline & & $\varepsilon_{1}(\mathrm{eV})$ & 0.480 & 0.583 & 0.765 & 1.042 & 0.480 & 0.456 & 0.428 & 0.412 & 0.480 & 0.510 & 0.531 & 0.532 \\
\hline & \multirow[t]{3}{*}{1800} & $\eta_{T P V}$ & 23.4 & 32.0 & 43.8 & 54.9 & 23.4 & 30.6 & 36.9 & 41.0 & 23.4 & 31.5 & 40.5 & 46.1 \\
\hline & & $P_{E L}\left(\mathrm{~W} / \mathrm{cm}^{2}\right)$ & 24.6 & 25.7 & 21.9 & 12.5 & 24.6 & 27.2 & 30.6 & 33.0 & 24.6 & 26.9 & 29.4 & 31.4 \\
\hline & & $\varepsilon_{1}(\mathrm{eV})$ & 0.445 & 0.537 & 0.699 & 0.951 & 0.445 & 0.420 & 0.391 & 0.374 & 0.445 & 0.470 & 0.486 & 0.485 \\
\hline & \multirow[t]{3}{*}{1600} & & 21.5 & 30.0 & 41.8 & 53.1 & 21.5 & 28.7 & 35.2 & 39.5 & 21.5 & 29.6 & 38.7 & 44.5 \\
\hline & & $P_{E L}\left(\mathrm{~W} / \mathrm{cm}^{2}\right)$ & 15.1 & 16.0 & 13.8 & 8.0 & 15.1 & 16.9 & 19.3 & 21.1 & 15.1 & 16.7 & 18.6 & 20.1 \\
\hline & & $\varepsilon_{1}(\mathrm{eV})$ & 0.411 & 0.491 & 0.636 & 0.860 & 0.411 & 0.384 & 0.355 & 0.337 & 0.411 & 0.430 & 0.441 & 0.438 \\
\hline & \multirow{3}{*}{1400} & $\eta_{T P V}$ & 19.2 & 27.7 & 39.5 & 50.7 & 19.2 & 26.4 & 33.2 & 37.8 & 19.2 & 27.3 & 36.5 & 42.6 \\
\hline & & $P_{E L}\left(\mathrm{~W} / \mathrm{cm}^{2}\right)$ & 8.6 & 9.3 & 8.2 & 4.8 & 8.6 & 9.8 & 11.5 & 12.7 & 8.6 & 9.7 & 11.1 & 12.1 \\
\hline & & $\varepsilon_{1}(\mathrm{eV})$ & 0.378 & 0.446 & 0.571 & 0.770 & 0.378 & 0.350 & 0.318 & 0.300 & 0.378 & 0.391 & 0.397 & 0.390 \\
\hline & \multirow[t]{3}{*}{1200} & $\eta_{T P V}$ & 16.5 & 24.8 & 36.5 & 47.8 & 16.5 & 23.6 & 30.6 & 35.6 & 16.5 & 24.4 & 33.8 & 40.1 \\
\hline & & $P_{E L}\left(\mathrm{~W} / \mathrm{cm}^{2}\right)$ & 4.4 & 4.9 & 4.5 & 2.7 & 4.4 & 5.2 & 6.3 & 7.1 & 4.4 & 5.5 & 6.1 & 6.8 \\
\hline & & $\varepsilon_{1}(\mathrm{eV})$ & 0.346 & 0.401 & 0.508 & 0.679 & 0.346 & 0.316 & 0.282 & 0.263 & 0.346 & 0.353 & 0.353 & 0.343 \\
\hline & \multirow{3}{*}{1000} & $\eta_{T P V}$ & 13.2 & 21.1 & 32.8 & 44.0 & 13.2 & 20.1 & 27.3 & 32.7 & 13.2 & 20.8 & 30.2 & 36.9 \\
\hline & & $P_{E L}\left(\mathrm{~W} / \mathrm{cm}^{2}\right)$ & 2.0 & 2.3 & 2.2 & 1.4 & 2.0 & 2.4 & 3.1 & 3.6 & 2.0 & 2.4 & 3.0 & 3.4 \\
\hline & & $\varepsilon_{1}(\mathrm{eV})$ & 0.317 & 0.359 & 0.444 & 0.588 & 0.317 & 0.284 & 0.247 & 0.226 & 0.317 & 0.317 & 0.310 & 0.296 \\
\hline & \multirow{3}{*}{800} & $\eta_{T P V}$ & 9.2 & 16.4 & 27.8 & 39.0 & 9.2 & 15.6 & 23.0 & 29.0 & 9.2 & 16.2 & 25.6 & 32.6 \\
\hline & & $P_{E L}\left(\mathrm{~W} / \mathrm{cm}^{2}\right)$ & 0.70 & 0.87 & 0.90 & 0.59 & 0.70 & 0.92 & 1.27 & 1.56 & 0.70 & 0.91 & 1.22 & 1.48 \\
\hline & & $\varepsilon_{1}(\mathrm{eV})$ & 0.293 & 0.318 & 0.382 & 0.496 & 0.293 & 0.255 & 0.213 & 0.189 & 0.293 & 0.283 & 0.268 & 0.249 \\
\hline & \multirow[t]{5}{*}{600} & $\eta_{T P V}$ & 4.8 & 10.5 & 20.9 & 31.8 & 4.8 & 10.0 & 17.1 & 23.7 & 4.8 & 10.4 & 19.2 & 26.7 \\
\hline & & $P_{E L}\left(\mathrm{~W} / \mathrm{cm}^{2}\right)$ & 0.16 & 0.23 & 0.28 & 0.20 & 0.16 & 0.24 & 0.39 & 0.53 & 0.16 & 0.24 & 0.37 & 0.50 \\
\hline & & $\varepsilon_{1}(\mathrm{eV})$ & 0.280 & 0.283 & 0.321 & 0.404 & 0.280 & 0.234 & 0.182 & 0.152 & 0.280 & 0.256 & 0.229 & 0.203 \\
\hline \multirow[t]{2}{*}{ (b) $1 \mathrm{JC}$ and $T_{\mathrm{c}}=127^{\circ} \mathrm{C}$} & & & \multicolumn{4}{|c|}{ Maximum $\eta_{T P V}$} & \multicolumn{4}{|c|}{ Maximum $P_{E L}$} & Maxims & $\mathrm{EL} \times \eta_{\mathrm{TPV}}$ & & \\
\hline & & $\rho_{\text {BSR }}$ & 0.00 & $\mathbf{0 . 6 0}$ & 0.90 & 0.99 & $\mathbf{0 . 0 0}$ & 0.60 & 0.90 & 0.99 & $\mathbf{0 . 0 0}$ & 0.60 & 0.90 & 0.99 \\
\hline Emitter temperature. $T_{e}\left({ }^{\circ} \mathrm{C}\right)$ & 2000 & $J_{M P}\left(\mathrm{~A} / \mathrm{cm}^{2}\right)$ & 123.0 & 95.91 & 57.12 & 22.92 & 123.0 & 131.0 & 140.7 & 146.8 & 123.0 & 115.4 & 110.4 & 110.6 \\
\hline & & $V_{M P} / V_{O C}$ & 79.79 & 82.49 & 85.49 & 88.11 & 79.79 & 80.34 & 81.66 & 83.58 & 79.79 & 81.30 & 82.82 & 83.94 \\
\hline & & $V_{O C} / \varepsilon_{1}$ & 80.77 & 85.15 & 88.33 & 88.72 & 80.77 & 86.65 & 93.66 & 97.56 & 80.77 & 85.90 & 91.42 & 94.97 \\
\hline & & & 71.81 & 76.10 & 80.69 & 84.53 & 71.81 & 72.53 & 74.06 & 76.18 & 71.81 & 74.16 & 76.35 & 77.75 \\
\hline & 1800 & $J_{M P}\left(\mathrm{~A} / \mathrm{cm}^{2}\right)$ & 90.23 & 70.87 & 42.83 & 17.26 & 90.23 & 96.99 & 105.3 & 110.7 & 90.23 & 85.37 & 82.50 & 83.20 \\
\hline & & $V_{M P} / V_{O C}$ & 78.52 & 81.33 & 84.45 & 87.22 & 78.52 & 79.08 & 80.39 & 82.34 & 78.52 & 80.09 & 81.66 & 82.80 \\
\hline & & $V_{o d} / \varepsilon_{1}$ & 78.09 & 83.02 & 86.71 & 87.28 & 78.09 & 84.48 & 92.33 & 96.89 & 78.09 & 83.75 & 89.91 & 93.94 \\
\hline & & & 69.74 & 74.28 & 79.13 & 83.26 & 69.74 & 70.49 & 72.05 & 74.22 & 69.74 & 72.23 & 74.54 & 76.00 \\
\hline & 1600 & $J_{M P}\left(\mathrm{~A} / \mathrm{cm}^{2}\right)$ & 63.65 & 50.60 & 30.78 & 12.60 & 63.65 & 69.43 & 76.15 & 80.70 & 63.65 & 61.01 & 59.72 & 60.70 \\
\hline & & $V_{M P} / V_{O C}$ & 77.06 & 79.96 & 83.26 & 86.16 & 77.06 & 77.61 & 78.95 & 80.89 & 77.06 & 78.67 & 80.30 & 81.48 \\
\hline & & $V_{O C} \mid \varepsilon_{1}$ & 74.76 & 80.37 & 84.65 & 85.48 & 74.76 & 81.75 & 90.54 & 95.94 & 74.76 & 81.04 & 87.99 & 92.60 \\
\hline & & & 67.30 & 72.11 & 77.32 & 81.71 & 67.30 & 68.06 & 69.72 & 71.92 & 67.30 & 69.92 & 72.38 & 73.92 \\
\hline & 1400 & $J_{M P}\left(\mathrm{~A} / \mathrm{cm}^{2}\right)$ & 42.69 & 34.46 & 21.40 & 8.83 & 42.69 & 47.31 & 53.05 & 56.66 & 42.69 & 41.61 & 41.40 & 42.79 \\
\hline & & $V_{M P} / V_{O C}$ & 75.34 & 78.35 & 81.79 & 84.88 & 75.34 & 75.92 & 77.23 & 79.19 & 75.34 & 77.01 & 78.71 & 79.89 \\
\hline & & $V_{o c} / \varepsilon_{1}$ & 70.56 & 76.97 & 82.03 & 83.18 & 70.56 & 78.17 & 88.20 & 94.61 & 70.56 & 77.55 & 85.44 & 90.85 \\
\hline & & $F F$ & 64.36 & 69.47 & 75.06 & 79.82 & 64.36 & 65.20 & 66.86 & 69.15 & 64.36 & 67.15 & 69.79 & 71.39 \\
\hline & 1200 & $J_{M P}\left(\mathrm{~A} / \mathrm{cm}^{2}\right)$ & 26.76 & 22.15 & 14.01 & 5.92 & 26.76 & 30.41 & 34.98 & 37.89 & 26.76 & 26.68 & 27.23 & 28.65 \\
\hline & & $V_{M P} / V_{O C}$ & 73.28 & 76.37 & 80.03 & 83.28 & 73.28 & 73.87 & 75.19 & 77.15 & 73.28 & 75.01 & 76.78 & 78.00 \\
\hline & & $V_{o c} / \varepsilon_{1}$ & 65.14 & 72.51 & 78.55 & 80.19 & 65.14 & 73.45 & 84.91 & 92.68 & 65.14 & $72 \vee 94$ & 82.00 & 88.39 \\
\hline & & $F F$ & 60.74 & 66.15 & 72.24 & 77.40 & 60.74 & 61.65 & 63.40 & 65.77 & 60.74 & 63.73 & 66.57 & 68.26 \\
\hline & 1000 & $J_{M P}\left(\mathrm{~A} / \mathrm{cm}^{2}\right)$ & 15.14 & 12.96 & 8.58 & 3.73 & 15.14 & 17.88 & 21.41 & 23.74 & 15. 14 & 15.64 & 16.61 & 17.98 \\
\hline
\end{tabular}


and unit-emissivity for the emitter (black-body) so that $\rho_{\mathrm{BSR}}$ provides a good approximation of the photon recycling efficiency, at least for $\rho_{\mathrm{BSR}}<0.99$. Finally, we assume a constant semiconductor refraction index of $n_{\text {int }}=3.5$ and a planar configuration (Fig. 1) in which the TPV cells do not see each other, so that $F_{c c}^{(e)}=0$, which directly implies that $A_{c} / A_{e}=F_{e c}$.

For each emitter temperature $\left(T_{e}\right)$, TPV cell temperature $\left(T_{c}\right)$, and BSR reflectivity $\left(\rho_{\mathrm{BSR}}\right)$ we will determine the bandgap energies $\left(\varepsilon_{k}\right.$, for $k$ ranging from 1 to $n$ ) that maximize three different merit functions: the efficiency $\eta_{\mathrm{TPV}}$, the power density $P_{E L}$, and the product $P_{E L} \times \eta_{\mathrm{TPV}}$. To find the optimum bandgap energies in each case we have used the multidimensional direct search Nelder-Mead algorithm [52]. The equations shown in Table 1 are solved using the specific methods explained in Refs. $[15,53]$.

\section{Results and discussion}

Tables 2-5 show the optimum bandgap energy $\left(\varepsilon_{k}\right)$, the efficiency $\left(\eta_{\mathrm{TPV}}\right)$, the power density $\left(P_{E L}\right)$ and the key TPV cell parameters $\left(U_{M P}, V_{M P}, V_{O C}\right.$ and $\left.F F\right)$ of optimized TPV devices as a function of the BSR reflectivity $\left(\rho_{\mathrm{BSR}}\right)$, the TPV cell temperature $\left(T_{c}\right)$, and the emitter temperature $\left(T_{e}\right)$. Tables 2 and 3 show the case of single junction TPV cells (1JC, $n=1$ ) operating at $T_{c}=27^{\circ} \mathrm{C}$ (Table 2) and $T_{c}=127^{\circ} \mathrm{C}$ (Table 3 ) and Tables 4 and 5 show the case of dual junction (2JC, $n=2)$ TPV cells operating at $T_{c}=27^{\circ} \mathrm{C}$ (Table 4) and $T_{c}=127^{\circ} \mathrm{C}$ (Table 5). The tables include results for three different maximized functions: TPV efficiency $\left(\eta_{\mathrm{TPV}}\right)$, power density $\left(P_{E L}\right)$ and $P_{E L} \times \eta_{T P V}$. Figs. 2 and 3 show the results given in Tables 2 and $4\left(T_{C}=27^{\circ} \mathrm{C}\right)$ for the specific case of $T_{e}=1400^{\circ} \mathrm{C}$. In these figures we have added the results obtained for the case of triple-junction TPV cells (3JC) which is not shown in the tables.

\subsection{Trade-off between efficiency and power density}

Fig. 2 shows the impact on both the efficiency and power density of the BSR reflectivity $\left(\rho_{\mathrm{BSR}}\right)$. When optimizing for maximum efficiency (solid lines), the TPV efficiency shows a sharp increase as $\rho_{\mathrm{BSR}} \rightarrow 1$. In this situation, most of the sub-bandgap radiation is effectively recycled, so that it is possible to increase the cell bandgap(s) (Fig. 3) to minimize the cell's recombination [33] and maximize the output voltage, leading to the highest TPV conversion efficiency.

Unfortunately, this increment in the efficiency is accompanied by a drastic decrease in the power density, which is attributed to the poor match between radiative spectrum and spectral response of the TPV cells (see Fig. 4). In this situation most of the radiative power is turned back to the emitter $\left(P_{\text {in }}\right)$ and the factor $P_{\text {out }}-P_{\text {in }}$ that appears in the denominator of Eq. (5) is drastically diminished.

For power density maximization (dashed lines in Figs. 2 and 3 ) we observe that both power density and efficiency increase with $\rho_{\mathrm{BSR}}$, but to a lesser extent than in the previous case. The efficiency increase in this case is mostly attributed to an increase in the output power density $\left(P_{E L}\right)$ and not just to a decrease of $P_{\text {out }}-P_{\text {in }}$; thus, this situation is less sensitive to the photon recycling efficiency (i.e. $\rho_{\mathrm{BSR}}$ ). This results in a lower optimum bandgap than in the case of that maximum efficiency is aimed at (Fig. 3). The lower bandgap allows maximizing the produced chemical energy within the TPV cell (note the extremely high values of $\left.V_{O C} / \varepsilon_{1}\right)$. The diminishment of optimum bandgap with $\rho_{\mathrm{BSR}}$ is attributed to the improved recycling of the luminescent photons emitted backwards within the cells. This effect allows cells to be operated at higher voltages 
Table 4

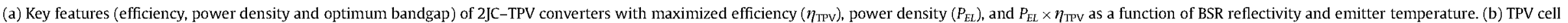

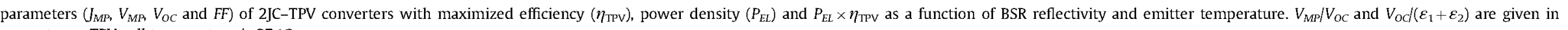
percentages. TPV cell temperature is $27^{\circ} \mathrm{C}$

\begin{tabular}{|c|c|c|c|c|c|c|c|c|c|c|c|c|c|c|}
\hline \multirow[t]{2}{*}{ (a) $2 \mathrm{JC}$ and $T_{c}=27^{\circ} \mathrm{C}$} & & \multirow[b]{2}{*}{$\rho_{\mathrm{BSR}}$} & \multicolumn{4}{|c|}{ Maximum $\eta_{T P V}$} & \multicolumn{4}{|c|}{ Maximum $P_{E L}$} & \multicolumn{4}{|c|}{ Maximum $P_{E L} \times \eta_{T P V}$} \\
\hline & & & 0.00 & 0.60 & 0.90 & 0.99 & 0.00 & 0.60 & 0.90 & 0.99 & 0.00 & 0.60 & 0.90 & 0.99 \\
\hline \multirow[t]{32}{*}{ Emitter temperature. $T_{e}\left({ }^{\circ} \mathrm{C}\right)$} & \multirow[t]{4}{*}{2000} & $\eta_{\mathrm{TPV}}$ & 40.5 & 46.7 & 55.6 & 64.4 & 40.5 & 45.1 & 48.6 & 50.6 & 40.5 & 46.1 & 51.9 & 55.2 \\
\hline & & $P_{E L}\left(\mathrm{~W} / \mathrm{cm}^{2}\right)$ & 61.6 & 60.3 & 47.7 & 25.5 & 61.6 & 63.5 & 65.7 & 67.3 & 61.6 & 62.9 & 63.9 & 64.8 \\
\hline & & $\varepsilon_{1}(\mathrm{eV})$ & 0.608 & 0.698 & 0.876 & 1.152 & 0.608 & 0.602 & 0.595 & 0.591 & 0.608 & 0.639 & 0.667 & 0.678 \\
\hline & & $\varepsilon_{2}(\mathrm{eV})$ & 0.333 & 0.461 & 0.673 & 0.976 & 0.333 & 0.326 & 0.317 & 0.313 & 0.333 & 0.380 & 0.417 & 0.426 \\
\hline & \multirow[t]{4}{*}{1800} & $\eta_{T P V}$ & 38.8 & 45.0 & 54.0 & 62.9 & 38.8 & 43.4 & 47.0 & 49.3 & 38.8 & 44.5 & 50.2 & 53.8 \\
\hline & & $P_{E L}\left(\mathrm{~W} / \mathrm{cm}^{2}\right)$ & 40.8 & 39.9 & 31.6 & 17.1 & 40.8 & 42.2 & 43.9 & 45.0 & 40.8 & 41.8 & 42.8 & 43.3 \\
\hline & & $\varepsilon_{1}(\mathrm{eV})$ & 0.558 & 0.643 & 0.803 & 1.054 & 0.558 & 0.552 & 0.544 & 0.540 & 0.558 & 0.586 & 0.604 & 0.620 \\
\hline & & $\varepsilon_{2}(\mathrm{eV})$ & 0.310 & 0.429 & 0.620 & 0.892 & 0.310 & 0.301 & 0.292 & 0.287 & 0.310 & 0.352 & 0.377 & 0.394 \\
\hline & \multirow[t]{4}{*}{1600} & $\eta_{T P V}$ & 36.7 & 43.1 & 52.1 & 61.1 & 36.7 & 41.4 & 45.2 & 47.6 & 36.7 & 42.5 & 48.5 & 52.2 \\
\hline & & $P_{E L}\left(\mathrm{~W} / \mathrm{cm}^{2}\right)$ & 25.7 & 25.3 & 19.9 & 10.9 & 25.7 & 26.7 & 27.9 & 28.8 & 25.7 & 26.5 & 27.1 & 27.6 \\
\hline & & $\varepsilon_{1}(\mathrm{eV})$ & 0.508 & 0.584 & 0.733 & 0.952 & 0.508 & 0.501 & 0.493 & 0.489 & 0.508 & 0.533 & 0.554 & 0.563 \\
\hline & & $\varepsilon_{2}(\mathrm{eV})$ & 0.285 & 0.393 & 0.570 & 0.811 & 0.285 & 0.276 & 0.267 & 0.262 & 0.285 & 0.323 & 0.351 & 0.360 \\
\hline & \multirow[t]{4}{*}{1400} & $\eta_{T P V}$ & 34.2 & 40.6 & 49.8 & 58.9 & 34.2 & 39.0 & 43.0 & 45.6 & 34.2 & 40.1 & 46.2 & 50.1 \\
\hline & & $P_{\mathrm{EL}}\left(\mathrm{W} / \mathrm{cm}^{2}\right)$ & 15.2 & 15.1 & 12.0 & 6.4 & 15.2 & 15.9 & 16.8 & 17.4 & 15.2 & 15.8 & 16.3 & 16.7 \\
\hline & & $\varepsilon_{1}(\mathrm{eV})$ & 0.458 & 0.526 & 0.655 & 0.861 & 0.458 & 0.451 & 0.443 & 0.438 & 0.458 & 0.481 & 0.497 & 0.506 \\
\hline & & $\varepsilon_{2}(\mathrm{eV})$ & 0.261 & 0.358 & 0.513 & 0.737 & 0.261 & 0.252 & 0.242 & 0.237 & 0.261 & 0.296 & 0.318 & 0.326 \\
\hline & \multirow[t]{4}{*}{1200} & $\eta_{T P V}$ & 31.1 & 37.6 & 46.9 & 56.1 & 31.1 & 36.1 & 40.3 & 43.2 & 31.1 & 37.1 & 43.5 & 47.6 \\
\hline & & $P_{\mathrm{FL}}\left(\mathrm{W} / \mathrm{cm}^{2}\right)$ & 8.31 & 8.27 & 6.64 & 3.63 & 8.31 & 8.77 & 9.34 & 9.75 & 8.31 & 8.68 & 9.05 & 9.35 \\
\hline & & $\varepsilon_{1}(\mathrm{eV})$ & 0.410 & 0.469 & 0.581 & 0.755 & 0.410 & 0.402 & 0.393 & 0.388 & 0.410 & 0.428 & 0.443 & 0.449 \\
\hline & & $\varepsilon_{2}(\mathrm{eV})$ & 0.238 & 0.324 & 0.458 & 0.649 & 0.238 & 0.228 & 0.218 & 0.213 & 0.238 & 0.268 & 0.287 & 0.291 \\
\hline & \multirow{4}{*}{1000} & $\eta_{T P V}$ & 27.2 & 33.8 & 43.3 & 52.7 & 27.2 & 32.3 & 36.9 & 40.2 & 27.2 & 33.0 & 40.0 & 44.5 \\
\hline & & $P_{E L}\left(\mathrm{~W} / \mathrm{cm}^{2}\right)$ & 4.05 & 4.07 & 3.32 & 1.83 & 4.05 & 4.33 & 4.69 & 4.95 & 4.05 & 4.31 & 4.53 & 4.74 \\
\hline & & $\varepsilon_{1}(\mathrm{eV})$ & 0.362 & 0.412 & 0.507 & 0.659 & 0.362 & 0.354 & 0.344 & 0.339 & 0.362 & 0.371 & 0.388 & 0.393 \\
\hline & & $\varepsilon_{2}(\mathrm{eV})$ & 0.216 & 0.290 & 0.404 & 0.567 & 0.216 & 0.206 & 0.194 & 0.189 & 0.216 & 0.230 & 0.256 & 0.258 \\
\hline & \multirow{4}{*}{800} & $\eta_{T P V}$ & 22.2 & 28.8 & 38.5 & 48.2 & 22.2 & 27.5 & 32.5 & 36.5 & 22.2 & 28.4 & 35.5 & 40.1 \\
\hline & & $P_{E L}\left(\mathrm{~W} / \mathrm{cm}^{2}\right)$ & 1.67 & 1.71 & 1.43 & 0.80 & 1.67 & 1.82 & 2.03 & 2.20 & 1.67 & 1.80 & 1.96 & 2.13 \\
\hline & & $\varepsilon_{1}(\mathrm{eV})$ & 0.316 & 0.357 & 0.435 & 0.566 & 0.316 & 0.307 & 0.296 & 0.290 & 0.316 & 0.327 & 0.335 & 0.331 \\
\hline & & $\varepsilon_{2}(\mathrm{eV})$ & 0.196 & 0.257 & 0.350 & 0.487 & 0.196 & 0.185 & 0.172 & 0.165 & 0.196 & 0.216 & 0.226 & 0.215 \\
\hline & \multirow[t]{4}{*}{600} & $\eta_{T P V}$ & 15.8 & 22.2 & 32.1 & 42.2 & 15.8 & 21.1 & 26.8 & 31.8 & 15.8 & 21.9 & 29.3 & 35.0 \\
\hline & & $P_{E L}\left(\mathrm{~W} / \mathrm{cm}^{2}\right)$ & 0.517 & 0.554 & 0.495 & 0.303 & 0.517 & 0.592 & 0.702 & 0.796 & 0.517 & 0.584 & 0.680 & 0.769 \\
\hline & & $\varepsilon_{1}(\mathrm{eV})$ & 0.274 & 0.303 & 0.361 & 0.463 & 0.274 & 0.263 & 0.249 & 0.241 & 0.274 & 0.279 & 0.278 & 0.275 \\
\hline & & $\varepsilon_{2}(\mathrm{eV})$ & 0.180 & 0.226 & 0.294 & 0.394 & 0.180 & 0.166 & 0.149 & 0.139 & 0.180 & 0.192 & 0.191 & 0.181 \\
\hline \multirow[t]{2}{*}{ (b) $2 \mathrm{JC}$ and $T_{c}=27^{\circ} \mathrm{C}$} & & & \multicolumn{4}{|c|}{ Maximum $\eta_{T P V}$} & \multicolumn{4}{|c|}{ Maximum $P_{E L}$} & Maxim & $P_{E L} \times \eta_{T P V}$ & & \\
\hline & & $\rho_{\text {BSR }}$ & 0.00 & 0.60 & 0.90 & 0.99 & 0.00 & 0.60 & 0.90 & 0.99 & 0.00 & 0.60 & 0.90 & 0.99 \\
\hline Emitter temperature. $T_{e}\left({ }^{\circ} \mathrm{C}\right)$ & 2000 & $J_{M P}\left(\mathrm{~A} / \mathrm{cm}^{2}\right)$ & 89.55 & 68.50 & 38.93 & 14.74 & 89.55 & 91.05 & 92.96 & 94.09 & 89.56 & 81.92 & 75.77 & 74.11 \\
\hline & & $V_{M P} / V_{O C}$ & 83.68 & 85.94 & 88.65 & 91.12 & 83.68 & 84.16 & 85.33 & 86.96 & 83.67 & 84.84 & 86.01 & 86.80 \\
\hline & & $V_{0}\left(\varepsilon_{1}+\varepsilon_{3}\right)$ & 87.38 & 88.41 & 89.18 & 89.16 & 87.38 & 89.26 & 90.86 & 91.26 & 87.38 & 88.88 & 90.42 & 91.21 \\
\hline & & $F F$ & 78.30 & 82.30 & 86.23 & 89.48 & 78.30 & 78.95 & 80.26 & 82.14 & 78.30 & 80.31 & 81.94 & 82.56 \\
\hline & 1800 & $J_{M P}\left(\mathrm{~A} / \mathrm{cm}^{2}\right)$ & 66.50 & 50.49 & 28.84 & 11.08 & 66.50 & 67.92 & 69.57 & 70.56 & 66.50 & 60.93 & 57.63 & 55.23 \\
\hline & & $V_{M P} V_{O C}$ & 82.60 & 85.00 & 87.85 & 90.29 & 82.60 & 83.06 & 84.22 & 85.63 & 82.60 & 83.80 & 84.94 & 85.85 \\
\hline & & $V_{O C} /\left(\varepsilon_{1}+\varepsilon_{2}\right)$ & 85.54 & 86.79 & 87.78 & 87.88 & 85.54 & 87.65 & 89.54 & 90.09 & $\begin{array}{l}82.00 \\
85.54\end{array}$ & $\begin{array}{l}03.00 \\
87.26\end{array}$ & $\begin{array}{l}04.94 \\
89.10\end{array}$ & 90.01 \\
\hline & & & 76.76 & 80.97 & 85.18 & 88.43 & 76.76 & 77.23 & 78.65 & 80.24 & 76.76 & 78.84 & 80.46 & 81.41 \\
\hline & 1600 & $J_{M P}\left(\mathrm{~A} / \mathrm{cm}^{2}\right)$ & 47.90 & 36.39 & 20.44 & 7.97 & 47.90 & 49.11 & 50.45 & 51.26 & 47.90 & 43.94 & 40.96 & 39.97 \\
\hline & & $V_{M P} / V_{O C}$ & 81.31 & 83.85 & 86.92 & 89.61 & 81.31 & 81.76 & 82.92 & 84.37 & 81.31 & 82.57 & 83.81 & 84.68 \\
\hline & & $V_{O C}\left(\varepsilon_{1}+\varepsilon_{2}\right)$ & 83.25 & 84.79 & 86.03 & 86.35 & 83.25 & 85.63 & 87.88 & 88.63 & 83.25 & 85.24 & 87.32 & 88.48 \\
\hline & & & 74.71 & 79.36 & 83.93 & 87.58 & 74.71 & 75.30 & 76.74 & 78.37 & 74.71 & 76.98 & 78.79 & 79.70 \\
\hline & 1400 & $J_{M P}\left(\mathrm{~A} / \mathrm{cm}^{2}\right)$ & 33.06 & 25.10 & 14.25 & 5.33 & 33.06 & 34.02 & 35.14 & 35.82 & 33.06 & 30.27 & 28.50 & 27.80 \\
\hline
\end{tabular}




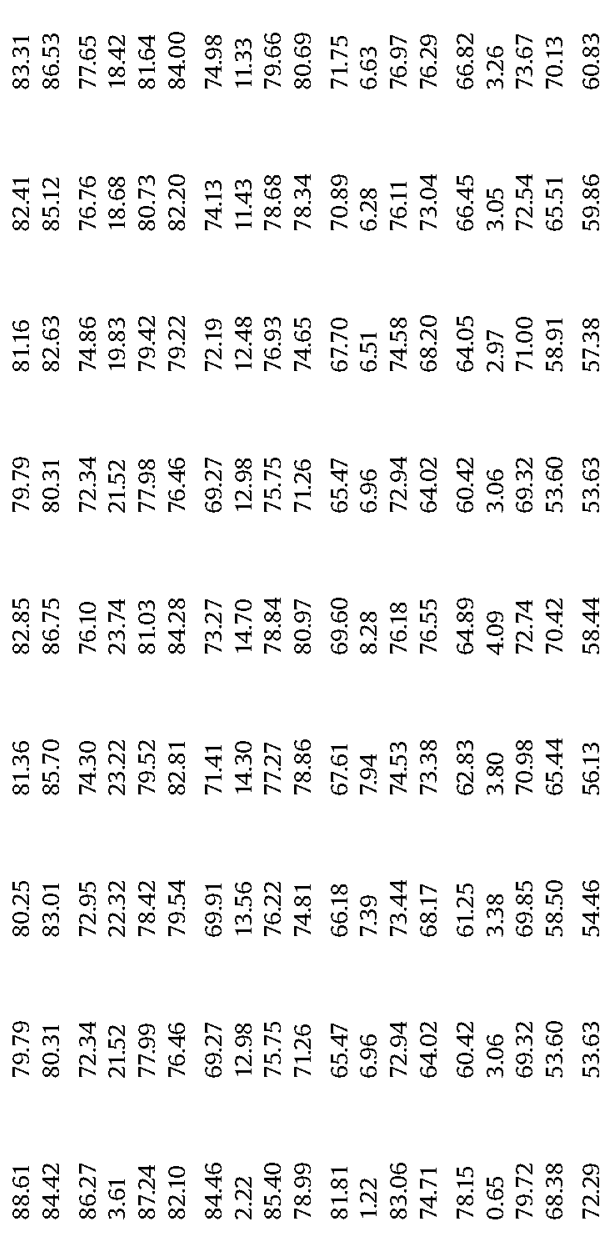

용욤ำ

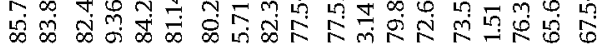

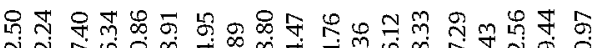

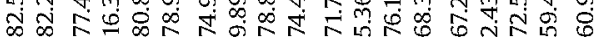

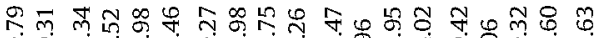

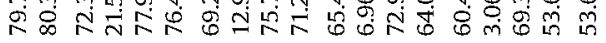

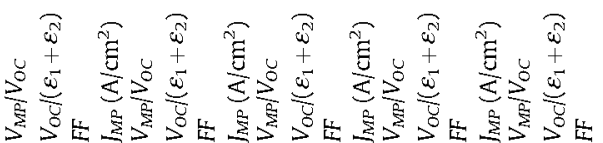

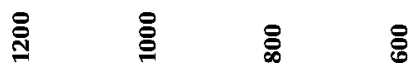

(note that $V_{M P} / V_{O C}$ and $F F$ increases) and therefore it becomes advantageous to slightly reduce the bandgap and absorb a higher amount of radiant power.

Different optimum bandgaps are obtained depending on whether we aim at maximizing the efficiency or the power density. However, both of them are important in TPV devices. Thus, a good merit function is the product of both of them, i.e. $P_{E L} \times \eta_{\mathrm{TPV}}$. The results of maximizing this function are represented by dash-dotted lines in Figs. 2 and 3 . The resultant value of $P_{E L} \times \eta_{\mathrm{TPV}}$ is shown in Fig. 2(c). We observe that the optimum bandgaps are just slightly higher than the obtained when maximizing the power density. Also, as in the case of maximum power density, the optimum bandgap is almost independent of $\rho_{\text {BSR, }}$, which facilities the proper choice of the semiconductor bandgap for a given emitter temperature.

From these results, we conclude that multijunction TPV cells enable the best trade-off between efficiency and the power density (i.e. maximizing the function $P_{E L} \times \eta_{\mathrm{TPV}}$ ). For instance, triple-junction TPV cells without any kind of photon recycling system $\left(\rho_{\mathrm{BSR}}=0\right)$ provide higher $P_{E L} \times \eta_{\mathrm{TPV}}$ than single junction cells with an ideal BSR $\left(\rho_{\text {BSR }} \rightarrow 1\right)$. Thus, multijunction TPV cells must be regarded as a promising solution for addressing the historical tradeoff between efficiency and power density in TPV devices. Furthermore, multijunction TPV cells provide high TPV theoretical efficiencies without the necessity of very efficient photon recycling system, as illustrated in Fig. 2(a).

It is worth noting that when $\rho_{\mathrm{BSR}} \rightarrow 0$, the three optimization strategies provide identical results. This is because $\rho_{\mathrm{BSR}}=0$ implies $P_{i n}=0$ and the denominator in Eq. (5) is constant ( $P_{\text {out }}$ depends only on the emitter temperature). Therefore, both efficiency and power density are proportional. This case is equivalent to solar-PV and CPV systems, where there is no recycling of photons between the solar cell and the heat source, i.e. the sun, and the output power is a direct measure of the system efficiency, given an input radiant power.

\subsection{Effect of photon recycling and TPV cell bandgap}

After the overall optimization of TPV converters presented in the previous section, in this section we analyze the sensitivity of the TPV converter performance to variations in two key parameters: BSR reflectivity $\left(\rho_{\mathrm{BSR}}\right)$ and TPV cell bandgap $\left(\varepsilon_{i}\right)$. This analysis is important because the bandgap and $\rho_{\mathrm{BSR}}$ values are generally constrained by technological limits and therefore, cannot be chosen arbitrarily.

Fig. 5 shows the efficiency of single junction TPV converters with fixed bandgap as a function of $\rho_{\text {BSR }}$, compared with the case in which the bandgap is optimized for each value of $\rho_{\text {BSR }}$. This figure shows that the TPV conversion efficiency is very sensitive to the photon recycling efficiency when using relatively high bandgap TPV cells (e.g. $0.7 \mathrm{eV}$ in the figure). Although high bandgap provides the highest overall conversion efficiency for $\rho_{\mathrm{BSR}} \rightarrow 1$, this efficiency sharply goes down for slight reduction of $\rho_{\text {BSR. This }}$ represents an additional drawback (together with the low output power density) of using relatively high bandgap semiconductors in TPV converters.

Fig. 6 shows the TPV efficiency and power density for both single junction (1JC) and dual junction (2JC) TPV cells as a function of the TPV cell bandgap. In the case of 2JCs, the abscissa represents the bottom cell bandgap and the top cell bandgap is optimized for each point. We observe that both efficiency and power density drastically decrease for bandgaps higher than the optimum. The efficiency may be recovered by using an efficient photon recycling system $\left(\rho_{\mathrm{BSR}} \rightarrow 1\right)$, but this has little effect on the power density. An important conclusion from these results is that multijunction TPV cells do not 
Table 5

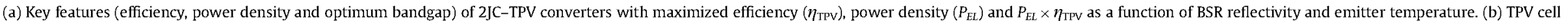

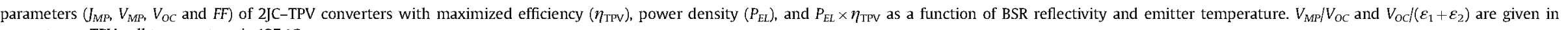
percentages. TPV cell temperature is $127^{\circ} \mathrm{C}$.

\begin{tabular}{|c|c|c|c|c|c|c|c|c|c|c|c|c|c|c|}
\hline \multirow[t]{2}{*}{ (a) $2 \mathrm{JC}$ and $T_{c}=127^{\circ} \mathrm{C}$} & & \multirow[b]{2}{*}{$\rho_{\text {BSR }}$} & \multicolumn{4}{|c|}{ Maximum $\eta_{\mathrm{TPV}}$} & \multicolumn{4}{|c|}{ Maximum $P_{E L}$} & \multicolumn{4}{|c|}{ Maximum $P_{E L} \times \eta_{\mathrm{TPV}}$} \\
\hline & & & 0.00 & 0.60 & 0.90 & 0.99 & 0.00 & 0.60 & 0.90 & 0.99 & 0.00 & 0.60 & 0.90 & 0.99 \\
\hline \multirow{32}{*}{ Emitter temperature, $T_{e}\left({ }^{\circ} \mathrm{C}\right)$} & \multirow[t]{4}{*}{2000} & $\eta_{T P V}$ & 34.6 & 41.0 & 50.2 & 59.2 & 34.6 & 39.4 & 43.4 & 46.0 & 34.6 & 40.5 & 46.6 & 50.4 \\
\hline & & $P_{E L}\left(\mathrm{~W} / \mathrm{cm}^{2}\right)$ & 52.6 & 51.9 & 41.4 & 22.2 & 52.6 & 54.9 & 57.8 & 59.8 & 52.6 & 54.4 & 56.1 & 57.5 \\
\hline & & $\varepsilon_{1}(\mathrm{eV})$ & 0.621 & 0.713 & 0.889 & 1.168 & 0.621 & 0.612 & 0.601 & 0.595 & 0.621 & 0.652 & 0.674 & 0.685 \\
\hline & & $\varepsilon_{2}(\mathrm{eV})$ & 0.353 & 0.485 & 0.694 & 0.995 & 0.353 & 0.341 & 0.328 & 0.321 & 0.353 & 0.400 & 0.431 & 0.439 \\
\hline & \multirow[t]{4}{*}{1800} & $\eta_{\mathrm{TPV}}$ & 32.4 & 38.9 & 48.2 & 57.3 & 32.4 & 37.4 & 41.5 & 44.2 & 32.4 & 38.4 & 44.7 & 48.6 \\
\hline & & $P_{E L}\left(\mathrm{~W} / \mathrm{cm}^{2}\right)$ & 34.1 & 33.8 & 26.9 & 14.7 & 34.1 & 35.8 & 37.9 & 39.4 & 34.1 & 35.4 & 36.8 & 37.9 \\
\hline & & $\varepsilon_{1}(\mathrm{eV})$ & 0.572 & 0.656 & 0.815 & 1.064 & 0.572 & 0.563 & 0.551 & 0.545 & 0.572 & 0.599 & 0.620 & 0.629 \\
\hline & & $\varepsilon_{2}(\mathrm{eV})$ & 0.330 & 0.450 & 0.643 & 0.912 & 0.330 & 0.317 & 0.303 & 0.297 & 0.330 & 0.372 & 0.399 & 0.405 \\
\hline & \multirow[t]{4}{*}{1600} & $\eta_{\mathrm{TPV}}$ & 29.8 & 36.4 & 45.8 & 55.1 & 29.8 & 35.5 & 39.2 & 42.3 & 29.8 & 35.9 & 42.4 & 46.7 \\
\hline & & $P_{E L}\left(\mathrm{~W} / \mathrm{cm}^{2}\right)$ & 20.9 & 20.8 & 16.8 & 9.1 & 20.9 & 22.0 & 23.7 & 24.8 & 20.9 & 21.9 & 22.9 & 23.7 \\
\hline & & $\varepsilon_{1}(\mathrm{eV})$ & 0.524 & 0.599 & 0.742 & 0.971 & 0.524 & 0.536 & 0.502 & 0.495 & 0.524 & 0.547 & 0.565 & 0.574 \\
\hline & & $\varepsilon_{2}(\mathrm{eV})$ & 0.307 & 0.416 & 0.587 & 0.834 & 0.307 & 0.324 & 0.280 & 0.273 & 0.307 & 0.344 & 0.369 & 0.375 \\
\hline & \multirow[t]{4}{*}{1400} & $\eta_{\mathrm{TPV}}$ & 26.8 & 33.4 & 42.9 & 52.4 & 26.8 & 31.9 & 36.5 & 39.9 & 26.8 & 32.9 & 39.7 & 44.2 \\
\hline & & $P_{E L}\left(\mathrm{~W} / \mathrm{cm}^{2}\right)$ & 11.9 & 12.0 & 9.8 & 5.4 & 11.9 & 12.7 & 13.8 & 14.6 & 11.9 & 12.6 & 13.3 & 14.0 \\
\hline & & $\varepsilon_{1}(\mathrm{eV})$ & 0.477 & 0.543 & 0.668 & 0.870 & 0.477 & 0.466 & 0.453 & 0.446 & 0.477 & 0.497 & 0.513 & 0.517 \\
\hline & & $\varepsilon_{2}(\mathrm{eV})$ & 0.286 & 0.383 & 0.532 & 0.748 & 0.286 & 0.272 & 0.256 & 0.249 & 0.286 & 0.320 & 0.340 & 0.340 \\
\hline & \multirow[t]{4}{*}{1200} & $\eta_{\mathrm{TPV}}$ & 23.1 & 29.7 & 39.3 & 49.0 & 23.1 & 28.3 & 33.3 & 37.2 & 23.1 & 29.2 & 36.3 & 40.9 \\
\hline & & $P_{E L}\left(\mathrm{~W} / \mathrm{cm}^{2}\right)$ & 6.15 & 6.29 & 5.24 & 2.98 & 6.15 & 6.70 & 7.43 & 7.99 & 6.15 & 6.62 & 7.16 & 7.71 \\
\hline & & $\varepsilon_{1}(\mathrm{eV})$ & 0.431 & 0.486 & 0.594 & 0.772 & 0.431 & 0.419 & 0.405 & 0.397 & 0.431 & 0.446 & 0.457 & 0.453 \\
\hline & & $\varepsilon_{2}(\mathrm{eV})$ & 0.265 & 0.350 & 0.477 & 0.660 & 0.265 & 0.250 & 0.233 & 0.225 & 0.265 & 0.293 & 0.308 & 0.297 \\
\hline & \multirow{4}{*}{1000} & $\eta_{T P V}$ & 18.6 & 25.2 & 35.0 & 44.9 & 18.6 & 23.9 & 29.4 & 33.9 & 18.6 & 24.8 & 322 & 37.8 \\
\hline & & $P_{E L}\left(\mathrm{~W} / \mathrm{cm}^{2}\right)$ & 2.76 & 2.90 & 2.49 & 1.46 & 2.76 & 3.09 & 3.55 & 3.93 & 2.76 & 3.05 & 3.42 & 3.75 \\
\hline & & $\varepsilon_{1}(\mathrm{eV})$ & 0.388 & 0.431 & 0.522 & 0.680 & 0.388 & 0.374 & 0.357 & 0.348 & 0.388 & 0.398 & 0.404 & 0.406 \\
\hline & & $\varepsilon_{2}(\mathrm{eV})$ & 0.248 & 0.317 & 0.423 & 0.576 & 0.248 & 0.231 & 0.211 & 0.200 & 0.248 & 0.269 & 0.277 & 0.272 \\
\hline & \multirow[t]{4}{*}{800} & $\eta_{T P V}$ & 13.2 & 19.5 & 29.4 & 39.5 & 13.2 & 18.5 & 24.4 & 29.7 & 13.2 & 19.2 & 27.0 & 33.2 \\
\hline & & $P_{E L}\left(\mathrm{~W} / \mathrm{cm}^{2}\right)$ & 0.99 & 1.09 & 1.00 & 0.61 & 0.99 & 1.16 & 1.43 & 1.66 & 0.99 & 1.15 & 1.37 & 1.59 \\
\hline & & $\varepsilon_{1}(\mathrm{eV})$ & 0.348 & 0.381 & 0.450 & 0.580 & 0.348 & 0.332 & 0.311 & 0.298 & 0.348 & 0.352 & 0.351 & 0.347 \\
\hline & & $\varepsilon_{2}(\mathrm{eV})$ & 0.234 & 0.287 & 0.369 & 0.493 & 0.234 & 0.214 & 0.188 & 0.173 & 0.234 & 0.246 & 0.246 & 0.232 \\
\hline & \multirow[t]{4}{*}{600} & $\eta_{\mathrm{TPV}}$ & 7.1 & 12.5 & 22.0 & 32.2 & 7.1 & 11.9 & 18.0 & 24.2 & 7.1 & 12.3 & 20.1 & 27.2 \\
\hline & & $P_{E L}\left(\mathrm{~W} / \mathrm{cm}^{2}\right)$ & 0.232 & 0.285 & 0.304 & 0.215 & 0.232 & 0.304 & 0.430 & 0.552 & 0.232 & 0.300 & 0.412 & 0.524 \\
\hline & & $\varepsilon_{1}(\mathrm{eV})$ & 0.319 & 0.333 & 0.376 & 0.475 & 0.319 & 0.296 & 0.266 & 0.249 & 0.319 & 0.312 & 0.301 & 0.293 \\
\hline & & $\varepsilon_{2}(\mathrm{eV})$ & 0.230 & 0.260 & 0.311 & 0.397 & 0.230 & 0.202 & 0.166 & 0.143 & 0.230 & 0.229 & 0.214 & 0.195 \\
\hline \multirow[t]{2}{*}{ (b) $2 \mathrm{JC}$ and $T_{c}=127^{\circ} \mathrm{C}$} & & & \multicolumn{4}{|c|}{ Maximum $\eta_{T P V}$} & \multicolumn{4}{|c|}{ Maximum $P_{E L}$} & Maximu & $E L \times \eta_{T P V}$ & & \\
\hline & & $\rho_{B S R}$ & 0.00 & 0.60 & 0.90 & 0.99 & 0.00 & 0.60 & 0.90 & 0.99 & 0.00 & 0.60 & 0.90 & 0.99 \\
\hline Emitter temperature, $T_{e}\left({ }^{\circ} \mathrm{C}\right)$ & 2000 & $J_{M P}\left(\mathrm{~A} / \mathrm{cm}^{2}\right)$ & 83.42 & 63.29 & 36.09 & 13.68 & 83.42 & 85.74 & 88.50 & 90.17 & 83.42 & 76.43 & 71.81 & 70.44 \\
\hline & & $V_{M P} / V_{O C}$ & 80.05 & 82.75 & 85.92 & 88.63 & 80.05 & 80.51 & 81.63 & 83.11 & 80.05 & 81.39 & 82.66 & 83.51 \\
\hline & & $V_{O C}\left(\varepsilon_{1}+\varepsilon_{2}\right)$ & 80.83 & 82.69 & 84.27 & 84.74 & 80.83 & 83.47 & 86.09 & 87.08 & 80.83 & 83.09 & 85.51 & 86.88 \\
\hline & & & 72.76 & 77.80 & 82.58 & 86.28 & 72.76 & 73.34 & 74.74 & 76.46 & 72.76 & 75.22 & 77.17 & 77.91 \\
\hline & 1800 & $J_{M P}\left(\mathrm{~A} / \mathrm{cm}^{2}\right)$ & 61.32 & 46.58 & 26.35 & 10.15 & 61.31 & 63.30 & 65.74 & 67.04 & 61.32 & 56.37 & 53.08 & 52.25 \\
\hline & & $V_{M P} / V_{O C}$ & 78.77 & 81.56 & 85.02 & 87.82 & 78.77 & 79.21 & 80.31 & 81.81 & 78.77 & 80.16 & 81.45 & 82.33 \\
\hline & & $V_{O C}\left(\varepsilon_{1}+\varepsilon_{2}\right)$ & 78.17 & 80.39 & 82.36 & 83.11 & 78.17 & 81.08 & 84.10 & 85.37 & 78.17 & 80.73 & 83.50 & 85.12 \\
\hline & & $F F$ & 70.70 & 76.01 & 81.37 & 85.22 & 70.70 & 71.20 & 72.63 & 74.46 & 70.70 & 73.35 & 75.24 & 76.01 \\
\hline & 1600 & $J_{M P}\left(\mathrm{~A} / \mathrm{cm}^{2}\right)$ & 43.41 & 33.00 & 18.85 & 7.14 & 43.41 & 41.96 & 47.03 & 48.20 & 43.41 & 40.09 & 37.78 & 37.14 \\
\hline & & $V_{M P} / V_{O C}$ & 77.27 & 80.20 & 83.68 & 86.65 & 77.27 & 78.31 & 78.81 & 80.33 & 77.27 & 78.71 & 80.10 & 81.04 \\
\hline & & $V_{O C}\left(\varepsilon_{1}+\varepsilon_{2}\right)$ & 74.86 & 77.55 & 80.02 & 81.08 & 74.86 & 77.90 & 81.60 & 83.26 & 74.86 & 77.81 & 81.02 & 82.97 \\
\hline & & & 68.13 & 73.95 & 79.44 & 83.61 & 68.13 & 69.90 & 70.22 & 72.11 & 68.13 & 71.02 & 73.22 & 74.09 \\
\hline & 1400 & $J_{M P}\left(\mathrm{~A} / \mathrm{cm}^{2}\right)$ & 29.20 & 22.25 & 12.87 & 4.97 & 29.20 & 30.58 & 32.27 & 33.21 & 29.20 & 26.98 & 25.58 & 25.59 \\
\hline
\end{tabular}




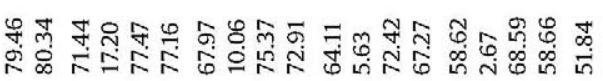

กิㅇํㅇำกติ

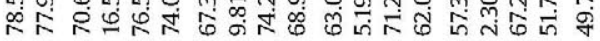

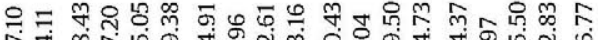
हिष्ठ

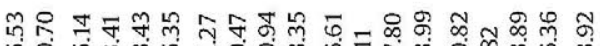

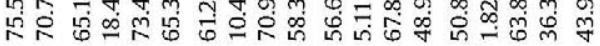

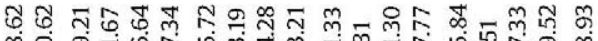

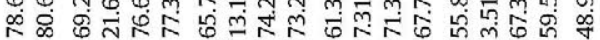

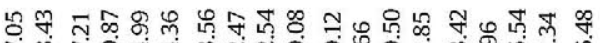

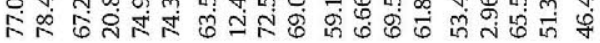

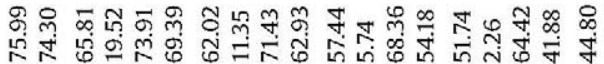

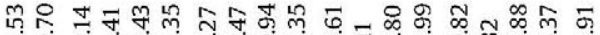

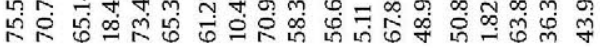

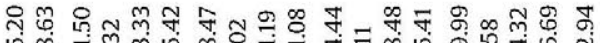

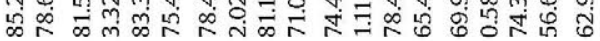

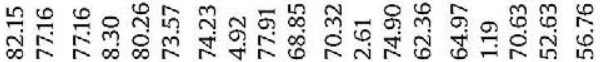
ถู่

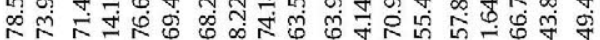

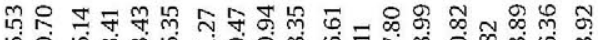

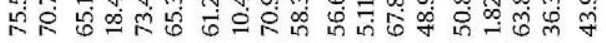
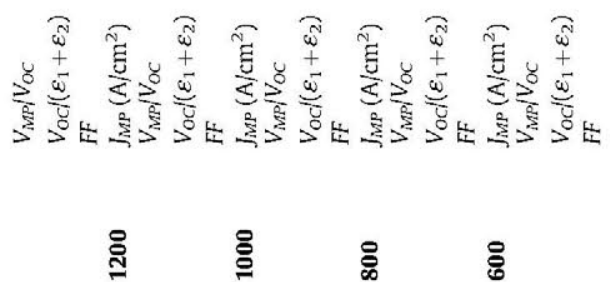

perform much better than single junction cells if the bottomcell bandgap is considerably higher than the optimum. This means that using low bandgap materials (below $0.5 \mathrm{eV}$ ) is essential in order to fully exploit the potential of multijunction TPV devices.

\subsection{Effect of TPV cell temperature}

TPV cells are typically irradiated by extremely high power densities; thus, they are expected to operate at considerably high temperatures. For example, according to the results of this paper, an optimized single junction TPV cell with $\rho_{\text {BSR }}=0.9$ irradiated by a black body emitter at $1400{ }^{\circ} \mathrm{C}$ (see Table 2 ) has to dissipate $12.5 \mathrm{~W} / \mathrm{cm}^{2}$ (heat absorbed by the cell not converted into electricity). Assuming a typical heat transfer coefficient of $0.15 \mathrm{~W} / \mathrm{cm}^{2} \mathrm{~K}$, corresponding to an active air-cooled heat-sink, this results in a cell temperature of $83^{\circ} \mathrm{C}$ above ambient. The effect of cell temperature on the optimum configurations is illustrated in Figs. 7 and 8. Fig. 7a shows the bandgap of a 1JC that maximizes the TPV efficiency (solid lines) as a function of the cell temperature. The actual bandgap of some semiconductor compounds is superimposed (dashed lines) for comparison. The resultant maximum TPV efficiency for both 1JCs and 2JCs is shown in Fig. 7b. Fig. 8a shows the same information than Fig. 7a for TPV cells which are optimized for power density, rather than efficiency. Fig. 8b shows the resultant maximum power density. In both cases the emitter temperature is $1400^{\circ} \mathrm{C}$.

The optimum bandgap increases with cell temperature in order to mitigate the increment of the radiative recombination at higher cell temperatures (Figs. 7a and 8a). In most of the cases, the lower recombination occasioned by the increment of bandgap compensates the reduced photogeneration. However, when $\rho_{\mathrm{BSR}}$ is extremely high and the backwards luminescence (radiative recombination) is effectively recycled, it may become favorable to enhance the photogeneration (reduce the bandgap) than minimize the recombination (increase the bandgap). This explains the slight reduction of the optimum bandgap with cell temperature for $\rho_{\text {BSR }}=0.99$ in Fig. $8(\mathrm{a})$.

Figs. $7 \mathrm{~b}$ and $8 \mathrm{~b}$ also show a greater impact of cell temperature on the performance of $2 \mathrm{JCs}$ than $1 \mathrm{JCs}$. This is simply explained by the fact that in 2JCs there are two temperature dependent sources of luminescence radiation (the two $\mathrm{p} / \mathrm{n}$ junctions) rather than just one in $1 \mathrm{JC}$.

Finally, notice that the bandgap dependence on temperature of real compounds must be taken into account in order to determine the actual optimum semiconductor to develop TPV cells under some particular cell operation temperature conditions. This is illustrated in both Figs. 7a and 8a.

\subsection{Technological concerns}

From the results shown in Tables $2-5$ it is evident that photocurrent densities are very high in most of the cases, especially for high temperature emitters and in TPV devices designed to provide the maximum power density. This introduces important technological drawbacks concerning the manufacturing of low resistive ohmic contacts in the TPV cell and the development of complex series-interconnection schemes, such as monolithic interconnected modules (MIMs) [54]. The use of multijunction cells reduces the photocurrent and increases the output voltage; thus mitigating the needs for a highly conductive electric contact and, eventually, reducing the number of required sub-modules in a MIM device.

Another technological challenge concerns the very low bandgaps (below $0.5 \mathrm{eV}$ ) that are needed in order to provide the 

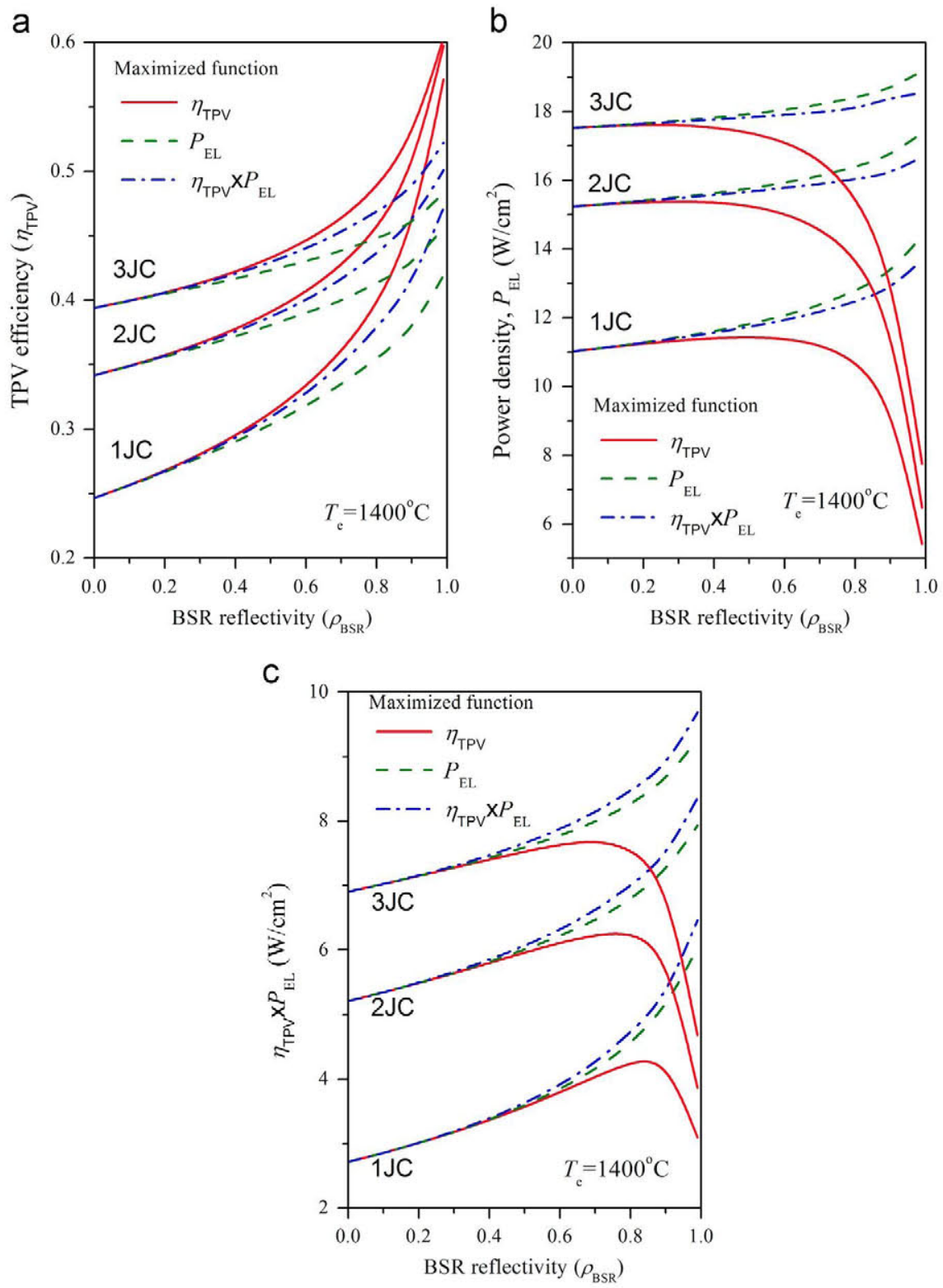

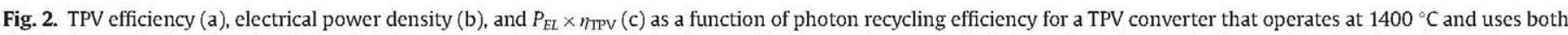

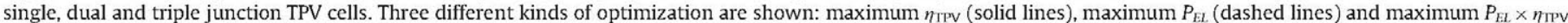
(dashed-dotted lines).

maximum power density and efficiency for a broad range of emitter temperatures. A number of semiconductor compounds have very low bandgaps, e.g.: InSb $(0.17 \mathrm{eV})$, InAs $(0.35 \mathrm{eV})$, InGaAsSb $(0.3-0.7 \mathrm{eV})$ and $\mathrm{PbS}(0.37 \mathrm{eV})$. However, the strong non-radiative recombination mechanisms existing in those low bandgap materials (especially Auger [30] and surface leakage currents [55]) should be taken into account for determining the actual optimum bandgaps. Consequently, if those materials have to be used, the optimum bandgaps calculated in this work under the assumption of only-radiative recombination [56] are surely underestimated. Thus, future research must focus on analyzing the effect of non-radiative recombination on the overall optimization of TPV converters. The results shown in this paper provide the upper limits for the TPV energy conversion and may guide the research towards the realization of high quality materials with the appropriate bandgaps for achieving the highest TPV performance. It worth noting that semiconductor nanostructures, such as quantum wells (QWs) and quantum dots (QDs), have the ability of suppressing Auger recombination [57]; thus, they must considered to be of particular interest for future low bandgap TPV cell developments.

\section{Conclusions}

The optimum bandgap(s) for single junction and multijunction TPV cells have been calculated based on detailed balance theory and assuming only radiative recombination. The optimization has been carried out on three different merit functions: efficiency, power density, and the product of both of them. Results have been provided as a function of the emitter temperature, cell temperature and photon recycling efficiency.

Owing to the effect of photon recycling, different optimum bandgaps are obtained depending on whether our aim is to 

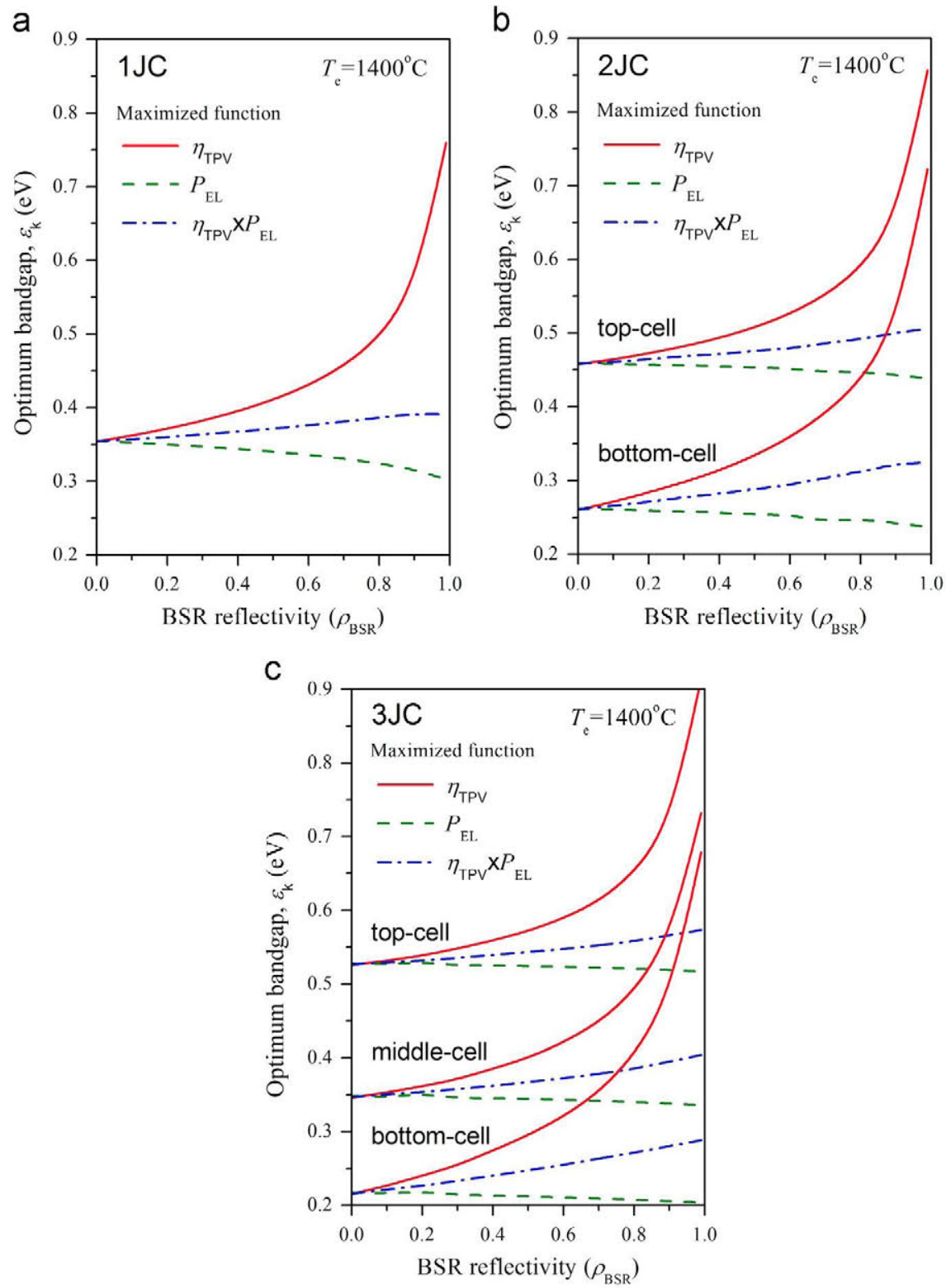

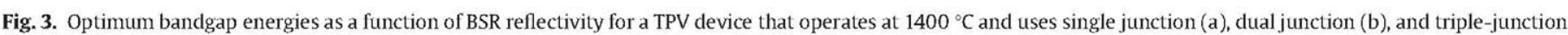
(c) TPV cells. Three different kinds of optimization are shown: maximum $\eta_{\mathrm{TPV}}$ (solid lines), maximum $P_{E L}$ (dashed lines) and maximum $P_{E L} \times \eta_{\mathrm{TPV}}$ (dashed-dotted lines).

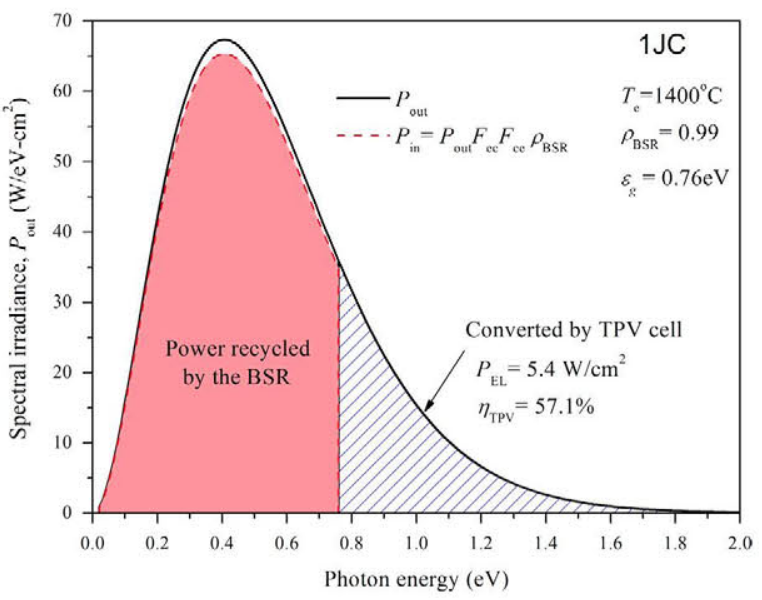

Fig. 4. Spectral irradiance for a blackbody at $1400^{\circ} \mathrm{C}$ operating a $0.76 \mathrm{eV}$ TPV cell with BSR reflectivity of $99 \%$. This illustrates how the achievement of maximum efficiency relies on the extremely high quality of the photon recycling process (i.e. high BSR reflectivity) and why the resultant power density is comparatively low.

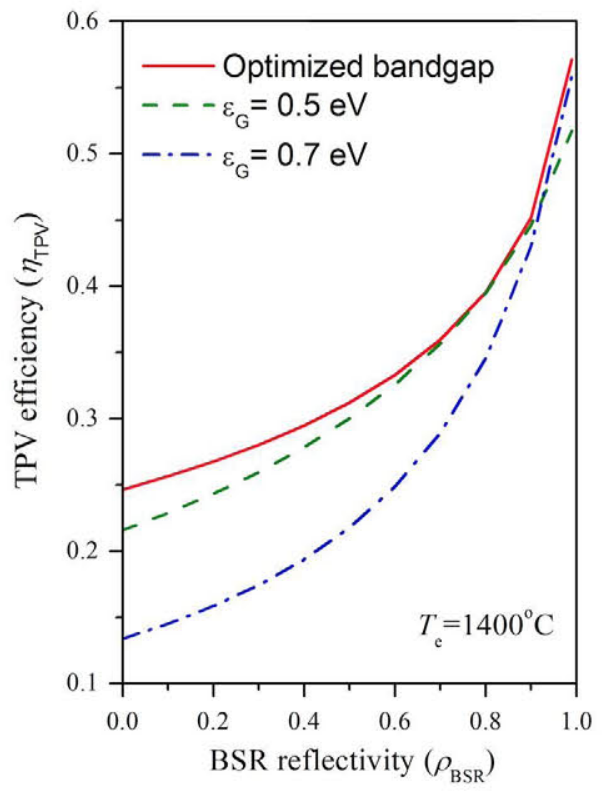

Fig. 5. TPV efficiency as a function of BSR reflectivity and TPV cell bandgap. The emitter temperature is $1400^{\circ} \mathrm{C}$ 

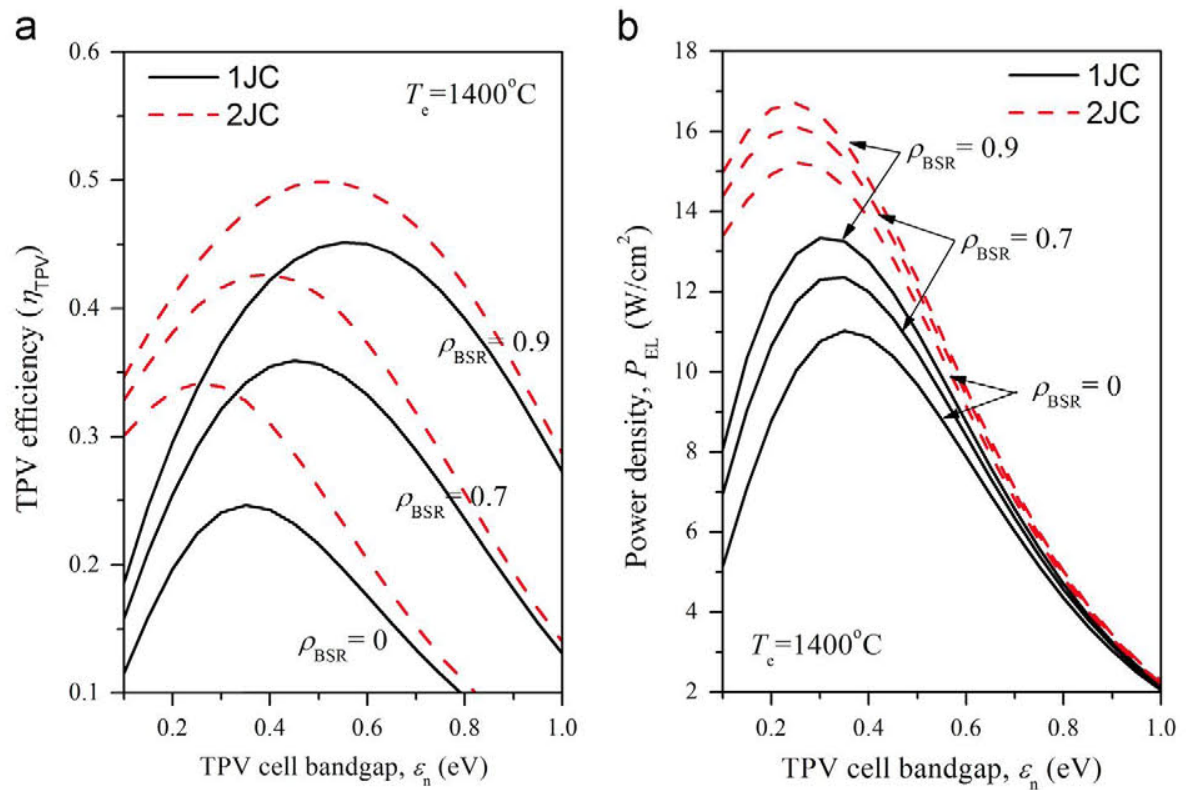

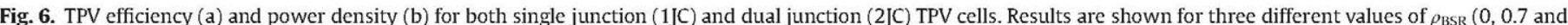

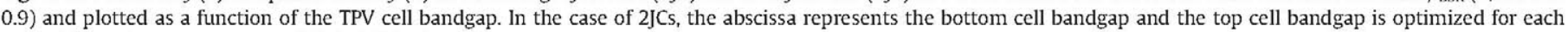
point. The emitter temperature $\left(T_{\mathrm{e}}\right)$ is $1400^{\circ} \mathrm{C}$.
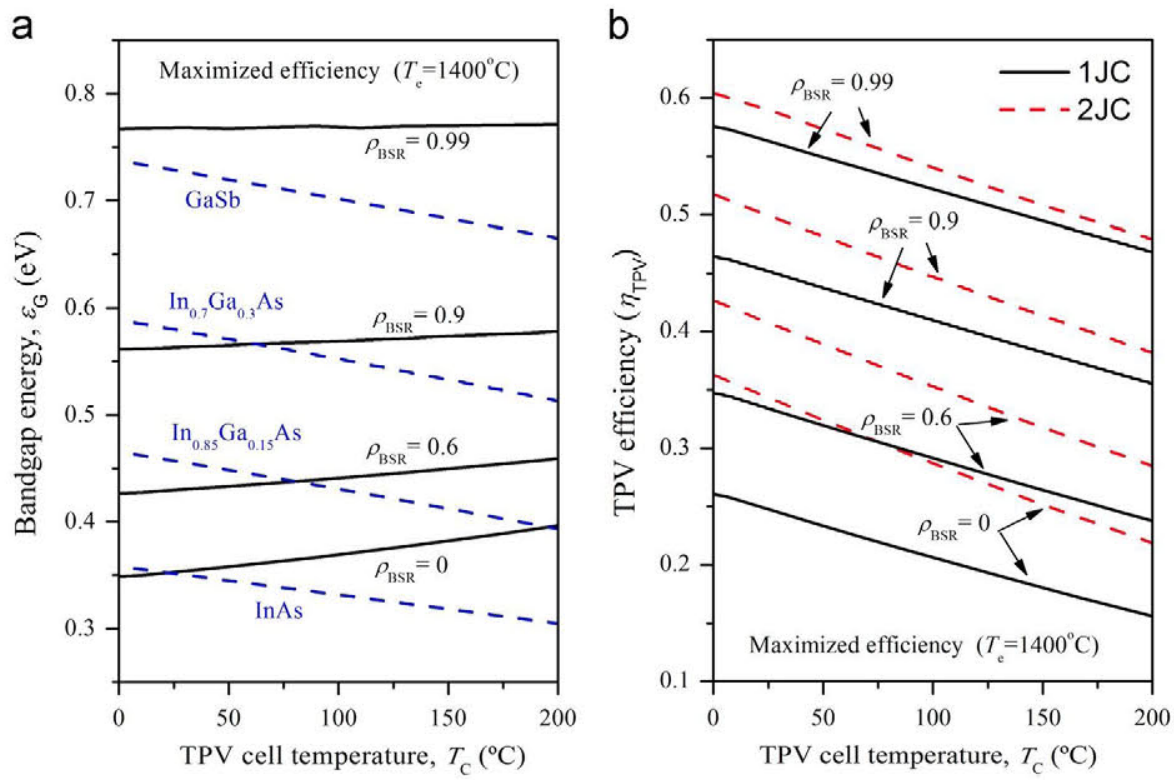

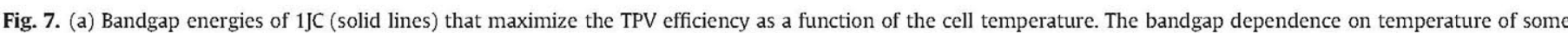

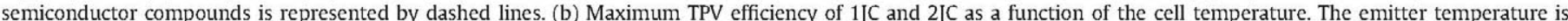
$1400^{\circ} \mathrm{C}$.

maximize the efficiency or the output power density. In general, higher bandgaps provide higher efficiencies at the expenses of lower power densities, and vice-versa. However, TPV devices using high bandgap cells are more sensitive to optical losses and consequently, an extremely high photon recycling efficiency is required.

Multijunction TPV cells have shown three key advantages: (1) maximize both the efficiency and the power density simultaneously, (2) mitigate the impacts of optical losses in the overall TPV system performance and (3) reduce the photocurrent and increase the voltage. In order to exploit the full potential of multijunction TPV devices, very low bandgaps (below $0.5 \mathrm{eV}$ ) are generally needed for the bottom cell. The strong non-radiative recombination mechanisms existing in low bandgap semiconductors may drastically deteriorate the performance of these devices. Quantum semiconductor structures, able to suppress Auger recombination, are promising candidates for developing future multijunction TPV cells. Future work must also focus on analyzing the effect of non-radiative recombination to identify the shortterm potential of multijunction TPV converters. 

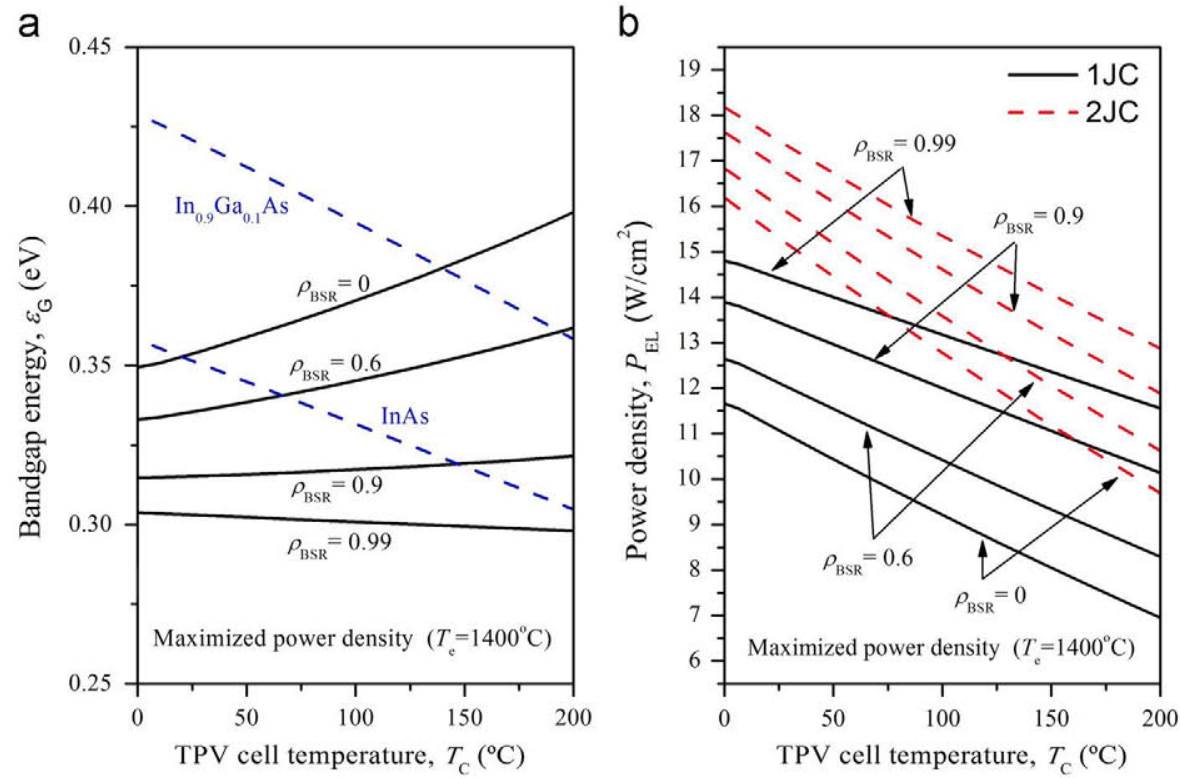

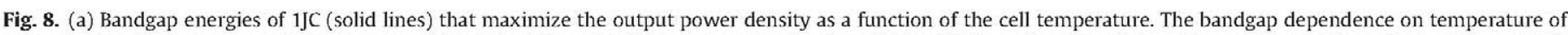

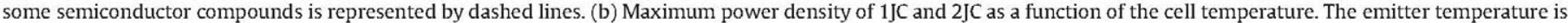
$1400^{\circ} \mathrm{C}$.

\section{Acknowledgement}

This work has been supported by Spanish National Research Program PROMESA (ENE2012-37804-C02-01). The author acknowledges valuable discussions with A. Martí and S. Askins (from IES-UPM) during the preparation of this manuscript.

\section{References}

[1] D.L. Chubb, Fundamentals of Thermophotovoltaic Energy Conversion, Elsevier 2007.

[2] T. Bauer, Thermophotovoltaics: Basic Principles and Critical Aspects of System Design, Springer, 2011.

[3] A. Datas, Development of Solar Thermophotovoltaic Systems, Universidad Politécnica de Madrid, Madrid, Spain, 2011.

[4] T. Bauer, I. Forbes, R. Penlington, N. Pearsall, The potential of thermophotovoltaic heat recovery for the glass industry, in: Presented at the Fifth Conference on Thermophotovoltaic Generation of Electricity, 2003, vol. 653, pp. 101-110.

[5] T. Bauer, I. Forbes, N. Pearsall, The potential of thermophotovoltaic heat recovery for the UK industry, Int. J. Ambient Energy 25 (1) (2004) 19-25.

[6] Z. Utlu, U. Parali, Investigation of the potential of thermophotovoltaic heat recovery for the Turkish industrial sector, Energy Convers. Manage. $74(0)$ (2013) 308-322.

[7] M. Bianchi, C. Ferrari, F. Melino, A. Peretto, Feasibility study of a thermophoto-voltaic system for CHP application in residential buildings, Appl. Energy (2012).

[8] W. Durisch, F. von Roth, W.J. Tobler, Advances in gas-fired thermophotovoltaic systems, J. Sol. Energy Eng.-Trans. ASME 129 (4) (2007) 416-422.

[9] W. Durisch, B. Bitnar, J.C. Mayor, F. von Roth, H. Sigg, H.R. Tschudi, G. Palfinger, Small self-powered grid-connected thermophotovoltaic prototype system, Appl. Energy 74 (1-2) (2003) 149-157.

[10] L.M. Fraas, J.E. Avery, H. Huang, Thermophotovoltaic furnace-generator for the home using low bandgap GaSb cells, Semicond. Sci. Technol. 18 (5) (2003) 247-253.

[11] L.M. Fraas, J.E. Avery, H.X. Huang, Thermophotovoltaics: heat and electric power from low bandgap 'solar' cells around gas fired radiant tube burners, in: Photovoltaic Specialists Conference, 2002. Conference Record of the TwentyNinth IEEE, 2002, pp. 1553-1556.

[12] A. Lenert, D.M. Bierman, Y. Nam, W.R. Chan, I. Celanovic, M. Soljacic E.N. Wang, A nanophotonic solar thermophotovoltaic device (Feb.), Nat. Nano 9 (2) (2014) 126-130.

[13] S. Fan, Photovoltaics: an alternative 'sun' for solar cells (Feb.), Nat. Nano 9 (2) (2014) 92-93.

[14] A. Datas, C. Algora, Development and experimental evaluation of a complete solar thermophotovoltaic system, Prog. Photovoltaics: Res. Appl. 21 (5) (2013) 1025-1039.

[15] A. Datas, C. Algora, Global Optimization of solar thermophotovoltaic systems, Prog. Photovoltaics: Res. Appl. 21 (5) (2013) 1040-1055.
[16] A. Datas, D.L. Chubb, A. Veeraragavan, Steady state analysis of a storage integrated solar thermophotovoltaic (SISTPV) system, Sol. Energy 96 (0) (2013) $33-45$.

[17] V.M. Andreev, A.S. Vlasov, V.P. Khvostikov, O.A. Khvostikova, P.Y. Gazaryan, S.V. Sorokina, N.A. Sadchikov, Solar Thermophotovoltaic converters based on tungsten emitters, J. Sol. Energy Eng. 129 (2007) 298-303.

[18] V.M. Andreev, V.A. Grilikhes, V.P. Khvostikov, O.A. Khvostikova, V.D. Rumyantsev, N.A. Sadchikov, M.Z. Shvarts, Concentrator PV modules and solar cells for TPV systems, Sol. Energy Mater. Sol. Cells 84 (2004) 3-17.

[19] F.E. Becker, E.F. Doyle, K. Shukla, Development of a portable thermophotovoltaic power generator, AIP Conf. Proc. 401 (1) (1997) 329-339.

[20] H. Xue, W. Yang, S.K. Chou, C. Shu, Z. Li, Microthermophotovoltaics power system for portable mems devices, Microscale Thermophys. Eng. 9 (1) (2005) 85-97.

[21] W.R. Chan, P. Bermel, R.C.N. Pilawa-Podgurski, C.H. Marton, K.F. Jensen, J.J. Senkevich, J.D. Joannopoulos, M. Soljacic, I. Celanovic, Toward highenergy-density, high-efficiency, and moderate-temperature chip-scale thermophotovoltaics, Proc. Nat. Acad. Sci. U.S.A. 110 (14) (2013) 5309-5314.

[22] V.L. Teofilo, P. Choong, J. Chang, Y.-L. Tseng, S. Ermer, Thermophotovoltaic energy conversion for space, J. Phys. Chem. C 112 (21) (2008) 7841-7845.

[23] K.W. Stone, R.E. Drubka, S.M. Kusek, M. Douglas, A Space Solar Thermophotovoltaic Power System, 1996, 1001-1006.

[24] D. J. Anderson, J. Sankovic, D. Wilt, R. D. Abelson, J. P. Fleurial, NASA's Advanced Radioisotope Power Conversion Technology Development Status, 2007, 1-20.

[25] M.R. Gilpin, D.B. Scharfe, M.P. Young, A.P. Pancotti, Molten Boron phasechange thermal energy storage to augment solar thermal propulsion systems," in: Presented at the 47th AIAA Joint Propulsion Conference, San Diego, CA (US), 2011

[26] M.R. Gilpin, D.B. Scharfe, M.P. Young, Phase-change thermal energy storage and conversion: development and analysis for solar thermal propulsion, in: Presented at the 48th AIAA/ASME/SAE/ASEE Joint Propulsion Conference \& Exhibit, Atlanta, GE (US), 2012.

[27] D.L. Chubb, B.S. Good, R.A. Lowe, Solar Thermophotovoltaic (STPV) System with Thermal Energy Storage, 1995, 181-198.

[28] B. Wernsman, R.R. Siergiej, S.D. Link, R.G. Mahorter, M.N. Palmisiano, W.R.J., Please confirm that given names and surnames have been identified correctly for author.R.W. Schultz, G.P. Schmuck, R.L. Messham, S. Murray, C.S. Murray, F. Newman, D. Taylor, D.M. DePoy, T. Rahmlow, Greater than $20 \%$ radiant heat conversion efficiency of a thermophotovoltaic radiator/module system using reflective spectral control, JEEE Trans. Electron Devices 51 (3) (2004) 512-515.

[29] L.M. Fraas, L. Minkin, TPV history from 1990 to present \& future trends, in: Presented at the AIP Conference Proceedings, 2007, vol. 890, p. 17.

[30] M.W. Dashiell, J.F. Beausang, H. Ehsani, G.J. Nichols, D.M. DePoy, LR. Danielson, P. Talamo, K.D. Rahner, E.J. Brown, S.R. Burger, P.M. Fourspring, W.F. Topper, P.F. Baldasaro, C.A. Wang, R.K. Huang, M.K. Connors, G.W. Turner, Z.A. Shellenbarger, G. Taylor, J. Li, R. Martinelli, D. Donetski, S. Anikeev, G.L. Belenky, S. Luryi, Quaternary InGaAsSb thermophotovoltaic diodes (Dec.), IEEE Trans. Electron Devices, 53 (12) (2006) 2879-2891.

[31] M.W. Dashiell, J.F. Beausang, G. Nichols, D.M. Depoy, L.R. Danielson, H. Ehsani, K.D. Rahner, J. Azarkevich, P. Talamo, E. Brown, S. Burger, P. Fourspring, W. Topper, P.F. Baldasaro, C.A. Wang, R. Huang, M. Connors, G. Turner, 
Z. Shellenbarger, G. Taylor, J. Li, R. Martinelli, D. Donetski, S. Anikeev, G. Belenky, S. Luryi, D.R. Taylor, J. Hazel, $0.52 \mathrm{eV}$ Quaternary InGaAsSb thermophotovoltaic diode technology, AIP Conf. Proc. 738 (1) (2004) 404-414.

[32] L. Fraas, M. Groeneveld, G. Magendanz, P. Custard, A single TPV cell power density and efficiency measurement technique, AIP Conf. Proc. 460 (1) (1999) 312-316.

[33] N.-P. Harder, P. Würfel, Theoretical limits of thermophotovoltaic solar energy conversion, Semicond. Sci. Technol. 18 (2003) S151-S157.

[34] A. Bett, F. Dimroth, R. Lockenhoff, E. Oliva, J. Schubert, III-V solar cells under monochromatic illumination, in: Photovoltaic Specialists Conference, 2008. PVSC '08. 33rd IEEE, 2008, pp. 1-5.

[35] A. Gombert, An overview of TPV emitter technologies, 2 Huntington Quadrangle, STE 1 no. 1, Melville, NY 11747-4501 USA, 2003, vol. 653, pp. 123-131.

[36] S. Basu, Z.M. Zhang, C.J. Fu, Review of near-field thermal radiation and its application to energy conversion, Int. J. Energy Res. 33 (13) (2009) 1203-1232.

[37] M. Francoeur, M.P. Mengüc, R. Vaillon, Control of near-field radiative heat transfer via surface phonon-polariton coupling in thin films, Appl. Phys. A 103 (3) (2011) 547-550.

[38] V.M. Andreev, V.P. Khvostikov, V.R. Larionov, V.D. Rumyantsev, S.V. Sorokina, M.Z. Shvarts, V.I. Vasil'ev, A.S. Vlasov, Tandem GaSb/lnGaAsSb thermophotovoltaic cells, in: Photovoltaic Specialists Conference, 1997, Conference Record of the Twenty-Sixth IEEE, 1997, pp. 935-938.

[39] Y. Hao-Yu, L. Ren-Jun, W. Lian-Kai, L. You, L. Tian-Tian, L. Guo-Xing, Z. YuanTao, Z. Bao-Lin, The design and numerical analysis of tandem thermophotovoltaic cells, Chin. Phys. B 22 (10) (2013) 108402.

[40] R. Siergiej, S. Sinharoy, R.J. Valko, R.J. Wherer, B. Wernsman, R.W. Link, S.D. Schultz, R.L. Messham, InGaAsP/InGaAs tandem TPV device, in: AIP Conference Proceedings, Freiburg, Germany, 2004, vol. 738, p. 480.

[41] R. Wehrer, M. Wanlass, D. Wilt, B. Wernsman, R. Siergiej, J. Carapella, InGaAs series-connected, tandem, MIM TPV converters, in: Photovoltaic Energy Conversion, 2003. Proceedings of Third World Conference on, 2003, vol. 1, pp. 892-895.

[42] S. Wojtczuk, Inverted Three-Junction Tandem Thermophotovoltaic Modules, NASA Tech Brief 20120016287, 2012

[43] R.K. Huang, C.A. Wang, M.K. Connors, G.W. Turne, M. Dashiell, Hybrid Back Surface Reflector GaInAsSb Thermophotovoltaic Devices. US Department of Energy, Jun-2004.

[44] L. B. Karlina, M. M. Kulagina, N. K. Timoshina, A. S. Vlasov, V. M. Andreev, In $(0.53) \mathrm{Gao}(0.47) \mathrm{As} / \mathrm{InP}$ conventional and inverted thermophotovoltaic cells with back surface reflector, in: Thermophotovoltaic Generation of Electricity vol. 890, 182-189, 2007.

[45] C.A. Wang, R.K. Huang, D.A. Shiau, M.K. Connors, P.G. Murphy, P.W. O'Brien, A.C. Anderson, D.M. DePoy, G. Nichols, M.N. Palmisiano, Monolithically seriesinterconnected GalnAsSb/AlGaAsSb/GaSb thermophotovoltaic devices with an internal back surface reflector formed by wafer bonding, Appl. Phys. Lett. 83 (7) (2003) 1286-1288

[46] J. Fernández, F. Dimroth, E. Oliva, M. Hermele, A.W. Bett, Back-surface optimization of Germanium TPV cells, AIP Conf. Proc. 890 (2006) 190-197.

[47] P. Abbott, A.W. Bett, Cell-mounted spectral filters for thermophotovoltaic applications, in: Presented at the AIP Conf. Proc., 2004, vol. 738, 244-251.

[48] H. Höfler, H.J. Paul, W. Ruppel, P. Würfel, Interference filters for thermophotovoltaic solar energy conversion, Sol. Cells 10 (1983) 273-286.

[49] K.A. Arpin, M.D. Losego, A.N. Cloud, H. Ning, J. Mallek, N.P. Sergeant, L. Zhu, Z. Yu, B. Kalanyan, G.N. Parsons, G.S. Girolami, J.R. Abelson, S. Fan, P.V. Braun, Three-dimensional self-assembled photonic crystals with high temperature stability for thermal emission modification, Nat. Commun. 4 (Oct.) (2013).

[50] I. Celanovic, N. Jovanovic, J. Kassakian, Two-dimensional tungsten photonic crystals as selective thermal emitters, Appl. Phys. Lett. 92 (2008) 193101.

[51] Y.X. Yeng, M. Ghebrebrhan, P. Bermel, W.R. Chan, J.D. Joannopoulos, M. Soljačić, I. Celanovic, Enabling high-temperature nanophotonics for energy applications, Proc. Nat. Acad. Sci. U.S.A. (2012).

[52] J. Lagarias, J. Reeds, M. Wright, P. Wright, Convergence properties of the Nelder-Mead simplex method in low dimensions, SIAM J. Optim. 9 (1) (Dec. 1998) 112-147.

[53] A. Datas, C. Algora, Detailed balance analysis of solar thermophotovoltaic systems made up of single junction photovoltaic cells and broadband thermal emitters, Sol. Energy Mater. Sol. Cells 94 (12) (2010) 2137-2147.

[54] D. Wilt, R. Wehrer, M. Palmisiano, M. Wanlass, C. Murray, Monolithic interconnected modules (MIMs) for thermophotovoltaic energy conversion (pp. PII S0268-1242(03), Semicond. Sci. Technol. 18 (5) (2003) 60134-60143.

[55] O.V. Sulima, A.W. Bett, P.S. Dutta, M.G. Mauk, R.L. Mueller, GaSb-, InGaAsSbInGaSb-, InAsSbP- and Ge-TPV cells with diffused emitters, in: Photovoltaic Specialists Conference, 2002. Conference Record of the Twenty-Ninth IEEE, 2002, pp. 892-895.

[56] G.D. Cody, Theoretical maximum efficiencies for thermophotovoltaic devices, AIP Conf. Proc. 460 (1) (1999) 58-67.

[57] G.E. Cragg, A.L. Efros, Suppression of Auger processes in confined structures, Nano Lett. 10 (1) (2010) 313-317. 